\title{
Rafet Metin
}

Kırıkkale University, rafet_metin71@hotmail.com, Kırıkkale-Turkey

\author{
http://dx.doi.org/10.12739/NWSA.2017.12.1.4C0214
}

\section{0-61/1844-45 TEMETTUAT KAYITLARI IŞIĞINDA KARACALI VE EYNE GAZİÜ̈ KÖYLERININ SOSYAL VE EKONOMIK GÖRÜNTÜSÜ}

Öz

Temettüat Defterleri XIX. yüzyıl Osmanlı sosyal ve ekonomik tarihinin önemli kaynaklarından biridir. Vergi kaynaklarını yeniden tespit ederek halkın üzerindeki vergi yükünü hafifletmek ve vergi dağılımında yaşanan adaletsizliği önlemek amacıyla hazırlanan temettuat kayıtları sosyo-ekonomik ve demografik yapının da ortaya konulmasında önemli bilgiler sunmaktadır. Kayıtlarda anılan dönemde bölgelerin mal-mülk, hayvan, arazi ve insanların şahsi mal varlıklarının kaydedilmesi ile sosyo-ekonomik hayat, nüfus ve tarımsal ekonomi ile ilgili bütün karakteristik özellikler ortaya konulmaktadır. Kayıtlarda ayrıca mükelleflerinin adları, lâkapları, meslekleri hakkında da bilgi alabilmek mümkün olmaktadır. Bu çalışmada, H.1260-1261/M.1844-1845 yılları arasında kaydedilen 761 ve 680 numaralı temettuat defterinden faydalanılarak, Kırıkkale ìlinin şirin köylerinden olan Karacalı ve Eyne Gazilü karyelerinin sosyal ve ekonomik yapıları ortaya konulmaya çalışılmıştır. Toplam 84 hanesi olan Karacalı karyesi ile 156 hanesi olan Eyne Gazilü karyesinde ikamet eden insanların geçimlerini büyük ölçüde tarım ve hayvancılıktan sağladıkları anlaşılmaktadır.

Anahtar Kelimeler: Temettüat Defteri, Hane, Vergi, Karye, Sosyal Yapı

\section{SOCIAL AND ECONOMIC FEATURES OF KARACALI AND EYNE GAZILÜ VILLAGES IN THE CONSIDERATION OF 1260-61/1844 TEMETTUAT REGISTERS}

\section{ABSTRACT}

Temettuat registers are one of the Ottoman's social and economic history's sources in $19^{\text {th }}$ Century. Temettuat registers were prepared for determine sources of taxation, ease burden of tax of community and prevent injustice situations in distribution of taxes. When viewed from this aspect, these registers present important information about social-economic and demographic structure. Regarding with cited period, properties, animals, lands and personal properties were registered in these documents. Thus, all characteristic features about social-economic life, population and agricultural economy were revealed. In these registers, it is also possible to obtain information about taxpayers' names, nicknames and jobs. In this study, benefiting basically 761 and 680 numbered temettuat registers which were enrolled between H.1260-1261 and M.1844-1845 years, it was tried to reveal social and economic structures of Karacalı and Eyne Gazilü villages which are adorable villages of Kırıkkale province. It is understood from registers that people who resident in Karacall village which has 84 section and Eyne Gazilü village which has 156 section make a living by doing agriculture and husbandry.

Keywords: Temettuat Registers, Section, Tax, Village, Social Structure

How to Cite:

Metin, R., (2017). 1260-61/1844-45 Temettuat Kayıtları Işığında Karacalı ve Eyne Gazilü Köylerinin Sosyal ve Ekonomik Görüntüsü, Humanities Sciences (NWSAHS), 12(1):9-34, DOI : $10.12739 /$ NWSA.2017.12.1.4C0214. 


\section{GIRIŞ (INTRODUCTION)}

Temettü' kâr etmek anlamına gelen Arapça bir kelimedir. Temettüat ise; kârlar, kazançlar anlamına gelmektedir (Devellioğlu, 1996:1073). Tanzimat'a kadar değişik adlarla halktan alınan vergilerin yerine getirilen Temettû vergisinin kaydedildiği defterlere, "Temettuat Defterleri" adı verilmiştir. Bu defterler 19. yüzyıl ortalarında Osmanlı Devleti'nin içinde bulunduğu iktisadi, sosyal ve ticari hayatı ortaya koymaktadır (Kütükoğlu, 1995:395). Temettuat defterleri genel itibariyle bir bölgenin demografik yapısı, hane reisinin menkul ve gayr-i menkul kaynakları, yıllık kazancı, işletmelerin büyüklüğü, iş gücü ve ayrıntılı vergi yükü, kişilerin mesleği, yetiştirilen zirâ̂ ürün ve hayvanlar ile ticarî ve sınầ müesseseler hakkında bilgiler sunmaktadır (Gül, 2009:81). Ayrıca anılan defterlerden Osmanlı ülkesinde yaşayan nüfusun yerleşim düzenini, zirai üretim durumunu, hanelerin servet ve gelirleri ile vergilendirme konularında çok zengin bilgiler elde etmek mümkün olmaktadır (Güran, 2000:79) .

Temettu vergisinin esası Tanzimat'tan evvel II.Mahmut zamanında H.1241 (M.1826) tarihinde ihdas olunan "ihtisab resmi"'dir. İhtisab resmi; şehriyye-i dekâkîn ve yevmiyye-i dekâkîn adıyla anılan vergilerle büyük yerleşim yerlerinde belediye geliri, pazar ve panayırlardan alınan damga, tartı, ölçü vs. vergileri, hile yapan esnafa kesilen para cezaları ve bütün yiyecek, içecek vs.'den alınan çeşitli vergilerden ibarettir (Serin, 1998:717). Kısaca bu defterlerden bir bölgenin Demografik etnik yapısı, fert düzeyinde menkul ve gayr-i menkul kaynaklar, ferdin yılıık kazancı, işletmelerin büyüklüğü, toplam ve ayrıntılı vergi yükünü, işgücünü, kişilerin mesleği, yetiştirilen zirai ürün ve hayvanlar, ticari ve sınai müesseseler hakkında önemli veriler elde edilmektedir (Özer, $2000: 596)$.

Çalışmamızın ana kaynağını teşkil eden Temettuat Defterlerinden BOA, ML VRD.TMT. 761 ile BOA, ML VRD.TMT.680 numaralarda kayıtlı günümüzde Kırıkkale İl hududunda bulunan Karacalı ve Eyne Gazilü karyelerinin sosyal ve ekonomik yapısı ortaya konulmaya çalışılmıştır. Her iki köyde de haneler birden başlayarak numaralandırılmış olup hanenin alt tarafına ise hane reislerinin isimleri ve şöhreti yazılmıştır. Eğer hane reisi evde yoksa veya merhum ise eşinin veya çocuklarının ismi yazılmıştır. Hanenin sağ üst tarafına, dikey olarak, uğraşmakta olduğu mesleği ve varsa özel durumunu belirten açıklamalar kaydedilmiştir. Mesleğine paralel olarak yan tarafına bir önceki sene vermiş olduğu "vergü-yi mahsusa"nın miktarı, sol üst tarafa ise hane reisinden alınan öşürlerin adları, miktarları ve toplamları, varsa adet-i ağnam (küçükbaş hayvan) vergisi yazılmıştır. "Vergü-yi mahsusa"nın yan tarafına ise hane reisinin köy dışında sahip olduğu emlak veya gayrı menkulleri not olarak tutulmuştur.

Yukarıda mevcut olan bilgilerin tamamı hane reisinin isminin üst tarafına yazılmıştır. Hane reisinin isminin alt tarafına ise; sağdan başlamak üzere kendisinin veya ailesinin sahip olduğu mezru ve gayrı mezru tarla (dönüm olarak) miktarı, mezru tarladan elde edilen gelirinin miktarı yazılmıştır. 1844 (1261 H.) yılı hasılatı ise tahmini olarak yazılmış ve bir önceki yılın hasılatı ile toplanmıştır. Hane sahibinin bağ ve bahçe gibi gayrı menkulleri ise dönüm şeklinde hesaplanmıştır. Hane sahibine ait diğer mal varlığı bilgileri yan tarafa ve alt tarafa yazılarak devam etmiştir. Hane sahibinin sahip olduğu büyük ve küçükbaş hayvanlar ile yük ve binek hayvanlarından elde edilen gelir yazılmıştır. Haneye ait tüm mal varlığının dökümü yapıldıktan sonra bu gelirlerin toplamı en alta yazılmış, bu rakamın altına varsa hane reisinin meslekten, ticaret ve sanatından, geliri, daha alta varsa hanenin yıl boyunca sabit olmayıp tahmini olarak 
ellerine geçtiği var sayılan "zuhurat" gelirler kaydedilip, toplamı alınarak vergiye esas hane geliri tespit edilmiştir. Bu şekilde tertip edilen temettuât defterlerinin sonuna o köy veya mahalleye ait toplam vergü-yi mahsusa ve yıllık toplam temettu miktarı yazılmış, birinci ve ikinci muhtar ve imam tarafından mühürlenmiştir. Defterin sonuna mührü vurmakla vazifeli olanlar, tahrir işleminin tam ve eksiksiz yapıldığını, herhangi bir şekilde istismara fırsat verilmediğini, adaletten ve hakkaniyetten ayrılmadığını belirten notu düştükten sonra mühürlemişlerdir. Her iki köyün tahrir edildiği defterler sarih bir dil ve düzgün cümlelerle ifade edilmiştir. Çalışmada anılan köylerin nüfusu ile birlikte köylerde kullanllan isimler, lakaplar, meslekî yapılanma, kazada yaşayan hane reislerinin tarım, hayvancılık ve meslek gelirleri ile birlikte ödemiş oldukları vergi çeşitleri tespit edilerek vergi yükleri ortaya konulmaya çalışılmıştır.

\section{2. ÇALIŞMANIN ÖNEMI (RESEARCH SIGNIFICANCE)}

Bu çalışmada, H.1260-1261/M.1844-1845 yılları arasında kaydedilen 761 ve 680 numaralı temettuat defterinden faydalanılarak, günümüzde Kırıkkale İlinin şirin köylerinden olan Karacalı ve Eyne Gazilü karyelerinin sosyal ve ekonomik yapıları ortaya konulmaya çalışılmıştır. Anılan karyelerde ikamet eden insanların nüfus yapıları, kullandıkları isimler, lakaplar, meslek dalları, hane reislerinin tarım, hayvancılık ve meslek gelirleri ile birlikte ödemiş oldukları vergi çeşitleri tespit edilerek vergi yükleri ortaya konulmaya çalışılmıştır.

\section{KARACALI KARYESI (VILLAGE OF KARACALI) \\ 3.1. Nüfus (Population)}

Karacalı karyesinin nüfusu ile ilgili en eski bilgi 1578-1579 tarihine ait bilgidir. Anllan tarihte yörük cemaatlerinden olan Karacalu/Karacalar cemaati 54 hane ve 68 mücerred ile Kırıkkale il bölgesine yerleşmiştir ${ }^{1}$. Hane $\mathbf{x}$ 5+ mücerred ${ }^{2}$ formülü ile toplam 338 kişilik bir nüfusu söz konusudur.761 numaralı temettuat defterinden tespit ettiğimiz kadarı ile 1844-1845 yılları arasında Karacalı karyesinin 84haneye tekâbül eden 420 neferlik nüfusu kayıt altına alınmıştır. ${ }^{3} 2007$ yılı adrese dayalı nüfus tespitine göre ise anılan köyde 365 kişi bulunmaktadır. ${ }^{4}$ (Tablo 1)

Tablo 1. Karacalı Karyesinde 1578-1845 yıllarındaki tahmini nüfus

(Table 1. Estimated population in Karacalı Village During 1578-1845)

\begin{tabular}{|c|c|}
\hline Ylllar & Tahmini Nüfus \\
\hline 1578 & 338 nefer \\
\hline 1845 & 420 nefer \\
\hline 2007 & 365 \\
\hline
\end{tabular}

\section{2. Şahıs Adları ve Kullanılan Lakaplar (Person Names and Used Nicknames}

761 numaralı temettüat defterinde hane reislerinin isimleri babalarının adları ve lakaplarıyla birlikte yazılmıştır. Bu nedenle köyde yaygın olarak kullanılan baba ve oğul isimlerini tespit etmek mümkün olmuştur.

\footnotetext{
1 Ahmet Kankal, XVI.Yüzyılda Çankırı, ,Çankırı Belediyesi Kültür Yayınları , Ocak 2009 Çankırı.s.102.

2 Bu hesaplama Ö.Lütfi Barkan'ın genel nüfusu bulmak için en çok kullanılan yöntem olan "hâne x 5" formülünden yola çıkılarak yapılmıştır. "Tarihî Demografi Araştırmaları ve Osmanlı Tarihi", Türkiyat Mecmuası, C X, İstanbul, 1953, s.12 (1-26)

3 BOA, ML.VRD.TMT, 761.s.1.

4 Günümüzde köyün ismi Karacaali olarak değiştirilmiştir.
} 
Tablo 2. Karacalı Karyesinde kullanılan şahıs isimleri

Table 2. Used person names in Karacalı Village)

\begin{tabular}{|c|c|c|}
\hline İsim & Sayı & $\frac{\circ}{0}$ \\
\hline Mehmed & 12 & 10.71 \\
\hline Hasan & 9 & 8.03 \\
\hline Osman & 7 & 6.25 \\
\hline Veli & 7 & 6.25 \\
\hline Hüseyin & 7 & 6.25 \\
\hline Osman & 7 & 6.25 \\
\hline Mustafa & 7 & 6.25 \\
\hline Halil & 5 & 4.46 \\
\hline Ahmed & 5 & 4.46 \\
\hline Ömer & 5 & 4.46 \\
\hline Musa & 5 & 4.46 \\
\hline Bâli & 4 & 3.5 \\
\hline İbiş & 3 & 2.6 \\
\hline Abdullah & 2 & 1.7 \\
\hline Ebu Bekir & 2 & 1.7 \\
\hline Süleyman & 2 & 1.7 \\
\hline Ramazan & 2 & 1.7 \\
\hline Turab & 2 & 1.7 \\
\hline İbrahim & 2 & 1.7 \\
\hline Yusuf & 2 & 1.7 \\
\hline Sevindi & 2 & 1.7 \\
\hline Mahmud & 2 & 1.7 \\
\hline İsmail & 2 & 1.7 \\
\hline Cuma & 1 & 1.7 \\
\hline Cemal & 1 & 1.7 \\
\hline Hamza & 1 & 1.7 \\
\hline Turhan & 1 & 1.7 \\
\hline Himmet & 1 & 1.7 \\
\hline Nabi & 1 & 1.7 \\
\hline Koçu & 1 & 1.7 \\
\hline Issa & 1 & 1.7 \\
\hline Çalab & 1 & 1.7 \\
\hline Toplam & 112 & 100.0 \\
\hline
\end{tabular}

Tablo 2'de yer alan verilerden anlaşıldığı üzere Karacalı karyesinde ki vergi nüfusunun tamamına yakını erkektir. İsimleri incelediğimizde diğer karyelerde olduğu gibi Peygamber ve onun ehl-i beyti başta olmak üzere daha çok Arapça kökenli isimlerin olduğu görülmektedir. Birinci surada Mehmed ismi gelmektedir. Mehmed ismi toplam isimlerin o10.71'initeşkil etmektedir. İkinci sırayı \%8.03 ile Hasan ismi almaktadır. Osman 06.25 ile üçüncü sırada yer almaktadır. Tabloda zikredilen isimler arasında Sevindi, Koçu, Çalab, Turab isimleri o dönemde yörede kullanılan ender isimler olarak karşımıza çıkmaktadır.

\subsection{Karacalı Karyesinde Kullanılan Lakaplar (Used Nicknames in Karacalı Village)}

Karacalı' da hane reislerinin toplumda tanınmasını sağlayan aile ve sülale adlarının bazıları dinî özellik taşımaktadır. Molla, Hatip, Hacı gibi unvanların yanında Tablo-3'te yer alan deli, kel, tombak, kara gibi slfatlarla birlikte kullanllan lakaplar ise muhtemelen ailelerin geçmişten beri kullana geldikleri lakaplar olarak görülmektedir. 
Tablo 3. Karacalı Karyesinde kullanılan lakaplar

(Table 3. Used nicknames in Karacalı Village)

\begin{tabular}{|l|l|l|}
\hline Hatip oğlu Ömer & İmam oğlu Molla Osman & Molla Hüseyin oğlu Veli \\
\hline Hacı Halil oğlu Mustafa & Deli onbaşı oğlu Ali & Kel Veli oğlu Veli \\
\hline Kara Mehmed & Tombak Musa & Kara oğlan oğlu Ahmed \\
\hline Deli Musa oğlu Hüseyin & Çolak Hasan & Kabasakal oğlu Ali \\
\hline Hüseyin Kethüda oğlu & Kaba Osman oğlu Mehmed & Tatar oğlu Musa \\
\hline Kel Hasan oğlu Hüseyin & Şarklı oğlu Mehmed & Şamlı Mehmed \\
\hline Kavlak Mehmed & Elçi oğlu İbiş & Mal Hasan \\
\hline Usta Osman oğlu Mehmed & Türab oğlu Ali & Bâli oğlu Molla Mustafa \\
\hline
\end{tabular}

\subsection{Karacalı Karyesinde Mesleki Yapılanma (Vocational Structuring in Karacalı Village)}

1844-1845 yılları arasında Karacalı karyesinde yaşayan insanların 60' z ziraat erbabındandır. Ziraatle iştigal edenlerin diğer meslek guruplarından farkları ekilebilir arazilerinin daha fazla ve yıllık temettuat oranlarının da daha yüksek olmasıdır5. Geriye kalan 24 haneden 10 tanesi hizmetkârlık ${ }^{6} 4$ tanesi köyde sözü sohbeti dinlenen kimselerin oluşturduğu irfan makulesinden ${ }^{7}, 1$ tanesi Imam $^{8} 1$ tanesi asker diğerleri ise hiçbir işi olmayan köy ahalisinin yardımı ile hayatlarını idame ettiren kimseler olarak kaydedilmiştir.

\subsection{Hayvancılık ve Hayvan Dağılımı (Husbandry and Animal Sharing)}

Belgelerden anlaşıldığına göre 1845-1846 yıllarında Karacalı karyesinde yaşayan haneler geçimlerini tarım ve hayvancılıktan sağlamakta idiler. Genel olarak süt ve süt ürünleri ihtiyaçlarını karşılamak için inek ve koyun, binek hayvanı ihtiyaçlarını karşılamak için merkep, çift sürmede faydalanabilmek için öküz kullandıkları anlaşılmaktadır. Karacalı' da toplam 400 olan hayvan varlığının büyük çoğunluğunu küçükbaş hayvanlar oluşturmaktadır. %54'üküçükbaş(216 adet), 27.5'i büyükbaş (110 adet) ve \%15.5'i yük ve binek (74 adet) hayvanı olarak sıralanmaktadır. Küçükbaş hayvan çeşidinde, koyun, keçi, kuzu ve oğlak beslenirken büyükbaş hayvan çeşidinde, karasığır öküzü, sağmal inek ve camus ön planda yer almıştır. Binek ve yük hayvanı olarak ise merkep beslenmektedir.

Tablo 4. Karacalı'da hane reislerinin sahip oldukları hayvan çeşitleri (Table 4. Household heads' animal types in karacall Village)

\begin{tabular}{|l|c|c|c|}
\hline Hayvan Çeşidi & Sayı & $\begin{array}{c}\text { Hayvan Sahibi } \\
\text { Hane }\end{array}$ & $\begin{array}{c}\text { Toplam Hane Başına } \\
\text { Düşen Baş }\end{array}$ \\
\hline Küçükbaş & 216 & 66 & 3.20 \\
\hline Büyükbaş & 110 & 70 & 1.50 \\
\hline Yük-Binek Hayvanı & 74 & 70 & 1.05 \\
\hline Toplam Sayı & 400 & 206 & 1.90 \\
\hline
\end{tabular}

\footnotetext{
5 BOA, ML VRD.TMT, 761.s.2 Köyün ilk muhtarı olan Veli kethüda oğlu Mehmed erbab-ı ziraatten olup yıllık 1200 akçe gelire sahiptir.

6 BOA, ML VRD.TMT, 761.s.5, 9, 11, 13, 32, 34 .

BOA, ML VRD.TMT, 761 .

8 BOA, ML VRD.TMT, 761.
} 
Metin, $R$.

Humanities Sciences (NWSAHS), 4C0214, 2017; 12(1): 9-34.

Tablo 5. Karacalı'da hane reislerinin sahip oldukları küçükbaş hayvan çeşitleri

(Table 5. Household heads' small cattle types in Karacalı Village)

\begin{tabular}{|l|r|r|r|}
\hline Küçükbaş Hayvan Çeşidi & \multicolumn{1}{|c|}{ Sayı } & Hane & Ortalama \\
\hline Koyun & 82 & 34 & 2.4 \\
\hline Keçi & 124 & 28 & 4.4 \\
\hline Kuzu & 4 & 1 & 4.0 \\
\hline Oğlak & 6 & 3 & 2.0 \\
\hline Toplam & 216 & 66 & 3.2 \\
\hline
\end{tabular}

Büyükbaş hayvanlara oranla daha fazla küçükbaş hayvan potansiyeline sahip olan Karacalı'da toplam 216 olan adet olan küçükbaş hayvanların tamamı 66 hanede bulunmaktadır. Bir hanede en fazla 10 en az 5 koyun bulunurken sadece bir hanede kıl keçisi yetiştirilmektedir. Sağmal keçi olarak kaydedilen keçi ise toplamda koyundan fazla beslenmektedir. Hem büyükbaş hem de küçükbaş hayvan besleyen kimselerin temettuat toplamı bakımından zengin kimseler sayıldıkları belgelerden anlaşılmaktadır. Köyün 60 numaralı hanesinde ikamet eden Çavuş oğlu Hasan'ın 1000 kuruşu bulan yılıık temettuat toplamında büyükbaş hayvanların yanı sıra on adet sağmal koyun beslediği anlaşılmaktadır. ${ }^{9}$ Köyün 57 numaralı hanesinde kayıtlı olan Tatar oğlu Halil'in yıllık 850 kuruş temettuatı içerisinde karasığır öküzü, camus ineği ile birlikte 10 sağmal keçiye sahip olduğu kayıtlara geçmiştir. ${ }^{10}$

Tablo 6. Karacalı'da hane reislerinin sahip oldukları büyükbaş hayvan çeşitleri

(Table 6. Household heads' cattle types in Karacalı Village)

\begin{tabular}{|l|r|r|r|}
\hline Büyükbaş Hayvan Çeşidi & \multicolumn{1}{|c|}{ Sayı } & Hayvan Sahibi Hane & \multicolumn{1}{c|}{ Ort. } \\
\hline Karasığır Öküzü & 64 & 34 & 1.80 \\
\hline Sağmal İnek & 32 & 31 & 1.03 \\
\hline Camus İneği & 8 & 6 & 1.30 \\
\hline Malak & 6 & 2 & 3.00 \\
\hline Toplam & 110 & 73 & 1.50 \\
\hline
\end{tabular}

Büyükbaş hayvan söz konusu olduğunda köylerde çift sürme işinde ilk olarak akla at ve katır gücü gelmektedir. Ancak il bölgesinde bulunan diğer köylerde olduğu gibi Karacalı'da öküzün ilk planda tercih edildiği görülmektedir. Belgelerden anlaşıldığı üzere anılan dönemde Karacalı'da karasığır öküzü ahalinin tarım yaparken kullandığı vazgeçilmez iş gücü kaynaklarından biri durumundadır. Köyde toplam 34 hanede karasığır öküzüne tesadüf edilmektedir. Öküz sahibi olmayan hanelerin bu yüzden ziraat yapacak durumlarının olmadığı bu yüzden ekilebilir durumdaki arazilerinin boş kaldığı kayıtlarda yer almaktadır. Köyün 75 numaralı hanesinde kayıtıı olan Hacı Halil oğlu Süleyman'ın bir öküzü olmadığı için 35 dönüm arazisinin boş kaldığı ve sürülemediği kaydedilmiştir. 11 Yük ve Binek Hayvanlarına gelince; Karacalı'da1845 yılında toplam 74 adet yük ve binek hayvanı bulunmaktadır. Bunların tamamı döllü merkep olarak tespit edilmiştir. Köyde ikamet eden 84 haneden 74 hanede döllü merkep bulunmaktadır. Ulaşım aracı olarak kullanılan merkebin fiyat olarak sağmal bir inek kadar değerinin olduğu kayıtlarda yer almaktadır. ${ }^{12}$

\footnotetext{
9 BOA, ML VRD.TMT, 761.s.29.

10 BOA, ML VRD.TMT, 761.s.28.

11 BOA, ML VRD.TMT, 761.s.38.

12 BOA, ML VRD.TMT,761.s.36 Köyün 71 numaralı hanesinde ikamet eden Çolak Hasan' ın 8 kuruşa tekâbül eden bir adet döllü merkep ve bir adet sağmal ineği vardır.
} 
Tablo 7. Karacalı'da hane reislerinin sahip oldukları yük ve binek hayvanı çeşitleri

(Table 7. Household heads' draught and mount animals types

in Karacalı village)

\begin{tabular}{|l|c|c|c|}
\hline Hayvan Çeşidi & Sayı & Hayvan Sahibi Hane & Ortalama \\
\hline Döllümerkeb & 74 & 70 & 1.05 \\
\hline Toplam & 74 & & \\
\hline
\end{tabular}

\subsection{Arazi Dağılımı ve Toprak Kullanımı} (Cultivated and Planted Agricultural Fields)

Karacalı'da hane reislerinin o62,7'si (60) buğday ve arpa tarımı ile alakalı zirâ̂ faaliyet içerisindedir. Köyde ikamet eden hanelerden 5,2'si bağcılık (72), 7, 4'ü penbe (pamuk) (60), 24,1'i Palamud ağacı (70) ve $\frac{0}{0}, 3^{\prime} i$ de meyve bahçesi ile iştigal etmektedir. Köyde çeşitli sebeplerden dolayı 460 dönüm arazide tarım yapılamamaktadır. Köyün 33 numaralı hanesinde kayıtıı olan Hatip oğlu Hüseyin'in tarım yapmaya kudreti olmadığı için 30 dönüm arazisinin boş kaldığı kaydedilmiştir. Buna mukabil üç dönüm penbe (pamuk) ve 10 dönümlük palamud ağacını yetiştirmekle iştigal ettiği belirtilmiştir. ${ }^{13}$ Köyün 16 numaralı hanesinde kayıtlı olan Kel Hasan oğlu Osman'ın mecnun olmasından dolayı 10 dönüm arazisini ekemediği kaydı düşülmüştür. ${ }^{14}$ Köyün bir numaralı hanesinde kayıtıı olan Bâli oğlu Mehmed'in köyde kendisinden başka hiçbir hanede tesadüf edilmeyen 10 dönümlük meyve ağacına sahip olduğu kayıtlarda yer almaktadır. ${ }^{15}$

Tablo 8. Karacalı'da ekili ve dikili tarım alanlarının dağılımı (Table 8. Distribution of cultivated and planted agricultural fields in Karacalı Village)

\begin{tabular}{|l|r|r|r|r|}
\hline Ekilebilir Arazi Türü & Miktar (Dönüm) & \multicolumn{1}{|c|}{ Hane } & \multicolumn{1}{c|}{ Ortalama } & \multicolumn{1}{c|}{ \% } \\
\hline Tarla (Buğday-Arpa) & 1676 & 60 & 27.9 & 62.7 \\
\hline Bağ & 140 & 72 & 1.9 & 5.2 \\
\hline Penbe (Pamuk) & 200 & 60 & 3.3 & 7.4 \\
\hline Palamud Ağacı & 645 & 70 & 9.2 & 24.1 \\
\hline Meyve Ağacı & 10 & 1 & 10 & 0.3 \\
\hline Toplam & 2671 & 263 & & 100.0 \\
\hline
\end{tabular}

\subsection{Gelirler (Incomes)}

\subsubsection{Tarım Gelirleri (Hasılatı) (Agricultural Incomes)}

1844-1845 yılları arası Karacalı'da ekili (tarla)tarım alanları(buğday-arpa) ve penbe (pamuk)toplam 1876 dönüm olup 22.717 kuruş gelir elde edilmiştir. Ekili tarım alanlarından ise 785 dönüm olan bağ ve palamuttan elde edilen gelir ise 5.594 kuruş olarak tespit edilmiştir.

Tablo 9. Karacalı'da ekili-dikili tarım alanlarının hasılatı

(Table 9. Cultivated agricultural land revenue in Karacalı)

\begin{tabular}{|l|r|r|r|}
\hline Ekilebilir Arazi Türü & $\begin{array}{c}\text { Miktar } \\
\text { (Kuruş) }\end{array}$ & $\begin{array}{c}\text { Miktar } \\
\text { (Dönüm) }\end{array}$ & Ortalama \\
\hline Tarla (Buğday-Arpa) & 19.348 & 1676 & 11.5 \\
\hline Bağ (Pamuk) & 3.188 & 140 & 22.7 \\
\hline Penbe & 3.369 & 200 & 16.8 \\
\hline Palamud & 2.406 & 645 & 3.7 \\
\hline Toplam & 28.311 & & \\
\hline
\end{tabular}

\footnotetext{
13 BOA, ML VRD.TMT, 761.s.17.

14 BOA, ML VRD.TMT, 761.s.8.

15 BOA, ML VRD.TMT, 761.s.1.
} 
Metin, $R$.

Humanities Sciences (NWSAHS), 4C0214, 2017; 12(1): 9-34.

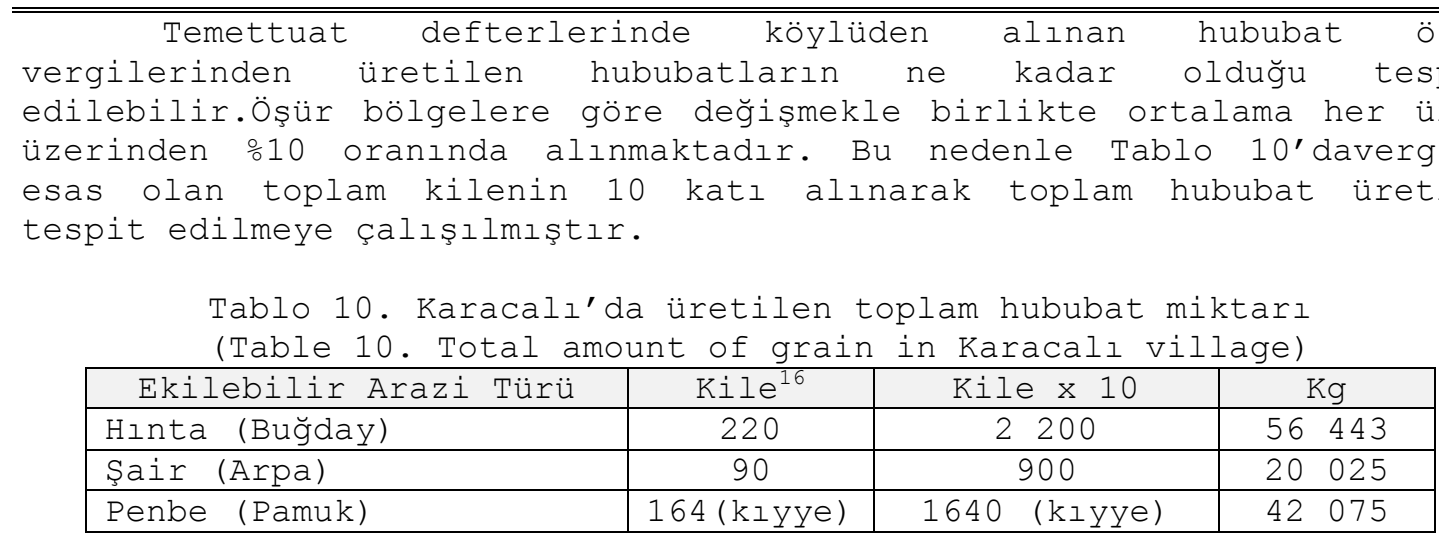

\subsubsection{Hayvancılık Hasılatı (Animal Husbandry Incomes)}

Karacalı'da tarımdan sonra ikinci sırada yer alan hayvancılık gelirleri 1.828 kuruştur. Hayvancılık hasılatı büyükbaş, küçükbaş ve yük-binek olarak üç grupta incelenebilir. Tablo 11'deki veriler incelendiğinde görüleceği üzere, hayvancılık hasılatında ilk sırayı küçükbaş hayvanlar almaktadır (1000 kuruş). İkinci sırada yük-binek hayvanları (488 kuruş)ve üçüncü olarak büyükbaş hayvanlar gelmektedir (340 kuruş). Bu sıralamada dikkat çeken husus yük-binek hayvanlarının tamamını döllü merkebin oluşturmasıdır. Toplam 84 hanenin hiçbirisinde kısrak ya da at beslenmemektedir. Küçükbaş hayvanlardan sağmal keçiden elde edilen yıllık gelir 682 kuruş, sağmal koyundan elde edilen yılıık gelir ise 318 kuruşa tekâbül etmektedir. Büyükbaş hayvanlardan ise sağmal karasığır ineğinden 240 kuruş sağmal camus ineğinden ise 100 kuruş yıllık gelir elde edilmiştir. Bir döllü merkeb ile bir sağman ineğin neredeyse aynı fiyat olması köyde yük-binek hayvanlarının önemini ortaya koymaktadır.

Tablo 11. Karacalı'da hayvancılık hasılatı dağılımı

(Table 11. Distribution of animal husbandry in Karacalı Village)

\begin{tabular}{|l|c|c|c|}
\hline Hayvan Çeşidi & Hasılat Miktarı Kuruş & Hayvan Sahibi Hane & Ort. \\
\hline Küçükbaş & 1000 & 66 & 15.15 \\
\hline Büyükbaş & 340 & 70 & 4.85 \\
\hline Yük-Binek & 488 & 70 & 6.97 \\
\hline Toplam Sayı & 1.828 & & \\
\hline
\end{tabular}

\subsubsection{Meslek Hasılatı (Vocational Incomes)}

Meslek gelirleri toplamda 1388kuruştur.Bu toplama meslek olarak kaydedilen imam, hizmetkârlık ve irfan makulesinden olduğu belirtilen ve ylllık ücret taktir edilen meslekler dahildir. Köyün büyük çoğunluğu "erbâb-ı ziraat" olarak kaydedilmiştir. Bu gurup meslek hasılatına dahil edilmemiştir. Köyün 15 numaralı hanesinde ikamet eden Cuma oğlu Mehmet, 17 numaralı hanesinde ikamet eden Usta Osman oğlu Mehmet, 18 numaralı hanesinde ikamet eden Hamza oğlu Mehmet, 22 numaralı hanesinde ikamet eden settar oğlu Mehmet, 23 numaralı hanesinde ikamet eden Kel Veli oğlu Veli, 26 numaralı hanesinde ikamet eden Kavlak Mehmet, 27 numaralı hanesinde ikamet eden Şarklı oğlu Mehmet, 33 numaralı hanesinde ikamet eden Hatip oğlu Hüseyin ve 34 numaralı hanesinde ikamet eden Molla Hüseyin oğlu Veli hizmetkarlıkla iştigal etmişler ve yllık toplamda 1088 kuruş gelir elde etmişlerdir. ${ }^{17}$ Köyün 34 numaralı hanesinde ikamet eden İbiş Kethüda

\footnotetext{
$16 \mathrm{Bu}$ çalışmada hesaplamalar yapılırken buğday ve pamuk için 1 kile (kıyye) =25, 656 kg.; arpa için isel kile=22,25kg. olarak alınmıştır.

17 BOA, ML VRD.TMT, 761.s.8,9,10,11,13,17,34.
} 
karındaşı Hüseyin, 52 numaralı hanesinde ikamet eden İmam oğlu Osman, 53 numaralı hanesinde ikamet eden İmam oğlu Halil ise irfan makulesinden olup toplamda yıllık 300 kuruş tutarında bir ücretle vazifelendirilmişlerdir. ${ }^{18}$ Köyün 72 numaralı hanesinde ikamet eden ve imam olduğu belirtilen Ali efendi için ise "Merkumun karye-i mezbûrda temettuata icâb edecek bir şeyi olmadığı ecilden merkumun an asl karye-i mezbûrede dahi olmadığı emlak ve arazisinin de bulunmadığı" kaydı düşülmüştür. ${ }^{19}$

\subsubsection{Vergü-yi Mahsusa}

1256/1840 yılından itibaren uygulanmaya başlayan ve bazı istisnalar haricinde ekonomik durumlarına göre herkesten alınan vergiyi mahsusa Tanzimat idarecileri tarafından örfi vergiler yerine konulmuş olup, "An-cemaatin vergi", "Vergü-yi Mahsusa", "Vergü" ve "Komşuca alınan vergü" gibi adlar verilmiştir. ${ }^{20}$ Karacalı'da tespit ettiğimize göre toplam vergü-yi mahsusa bedeli 18.029 kuruştur. ${ }^{21}$ Vergü-yi mahsusa olarak en düşük vergi 14 kuruş, en yüksek vergi ise 437kuruştur. Köyün 83 numaralı hanesinde kayıtlı olan Hamzanın oğlu Ömer'e 14 kuruşluk vergü-yi mahsusa bedeli taktir edilmiştir. ${ }^{22} 24$ numaralı hanede kayıtıı olan İbiş kethüdaya ise 437 kuruş vergü-yi mahsusa bedeli kaydedilmiştir. ${ }^{23}$

Tablo 12. Karacalı'da hane reislerinin verdiği toplam öşür ve aded-i ağnam vergisi

(Table 12. Total Amount of Öşür and Aded-i Ağnam Taxes given by Household Heads in Karacalı)

\begin{tabular}{|l|l|r|r|r|}
\hline $\begin{array}{l}\text { Ekili Tarım Öşrü ve Aded-i Ağnam } \\
\text { Vergisi }\end{array}$ & Miktar (Kuruş) & Hane & \multicolumn{1}{l|}{ Ort. } & \multicolumn{1}{c|}{} \\
\hline Hınta (Buğday) & 1466 & 57 & 25.7 & 45.2 \\
\hline Şair (Arpa) & 732 & 57 & 12.8 & 22.5 \\
\hline Penbe (Pamuk) & 182 & 41 & 4.4 & 5.6 \\
\hline Bağ & 566 & 74 & 7.6 & 17.4 \\
\hline Palamud & 220 & 54 & 4.07 & 6.7 \\
\hline Aded-i Ağnam & 75 & 22 & 3.4 & 2.3 \\
\hline Toplam & 3.241 & & & 100.0 \\
\hline
\end{tabular}

Toplu olarak verdiğimiz vergi türlerinden ekili tarım üzerinden alınan öşür vergisi ile alâkalı olarak hınta (buğday) \%45.2 ile ilk sırada gelmektedir. Onu 을 2.5 ile şair (arpa), ⒘4 ile bağ, \%6.7 ile palamud, ⒌6 ile penbe (pamuk) izlemektedir. Ağnam vergisi ise 2.3 olarak tespit edilmiştir. Bu verilerden anlaşıldığına göre Karacalı'da en düşük vergi çeşidi ağnam olurken en yüksek vergi çeşidi ise hınta (buğday) olarak görülmektedir.

\footnotetext{
$18 \mathrm{BOA}, \mathrm{ML}$ VRD.TMT, $761 . \mathrm{s} .25,32,34$.

19 BOA, ML VRD.TMT,761.s.40.

20 Said Öztürk, (2000). Temettuat Tahrirleri. Akademik Araştırmalar Dergisi Osmanlı Özel Sayısı: Sayı: 4-5, s.537.

21761 numaralı temettuat defterinin sonunda toplam olarak verilen vergi-yi mahsusa bedeli 18.598 kuruş olarak belirtilmiştir. Bizim tespitimizle arasında 569 kuruşluk bir fark söz konusudur.Bu meblağın sehven yazıldığı kanaatindeyiz; Çünkü tespit ettiğimiz 18.029 kuruş vergi-yi mahsusa bedeli tek tek hanelerin taranmasıyla elde edilmiştir.

22 BOA, ML VRD.TMT, 761.s.42.

$23 \mathrm{BOA}, \mathrm{ML}$ VRD.TMT, $761 . \mathrm{s} .12$.
} 
Tablo 13. Karacalı'da ikâmet eden kimselerin hane sırasına göre toplam temettuatlari

(Table 13. Persons' temettuats according to household sequencing who resident in Karacalı)

\begin{tabular}{|c|c|c|}
\hline $\begin{array}{l}\text { Hane } \\
\text { No }\end{array}$ & Kişi Adı & Temettuat Toplamı Kuruş \\
\hline 1 & Bâli oğlu Mehmet & 422 ziraatçı \\
\hline 2 & Musa Kethüda oğlu Mehmed & 1200 ziraatçı \\
\hline 3 & Veli Kethüda oğlu Mehmed & 1200 ilk muhtar \\
\hline 4 & Türab oğlu Ali & 360 ikinci muhtar \\
\hline 5 & $\begin{array}{l}\text { Bâli oğlu Hacı veli'nin } \\
\text { yetimleri Ömer ve Karındaşı } \\
\text { Mustafa ve valideleri Cennet }\end{array}$ & 466 ziraat yapmakta oldukları \\
\hline 6 & Bâli oğlu Molla Mustafa & 500 ziraatçı \\
\hline 7 & Tombak Musa & 850 zıraatçı \\
\hline 8 & Kel oğlan İsmail & 508 zıraatçı \\
\hline 9 & Karaoğlan oğlu Ahmed & $\begin{array}{l}245 \text { hasta olduğu ve hizmetkârlığa } \\
\text { bile imkanı olmadığı }\end{array}$ \\
\hline 10 & Deli onbaşı oğlu Ali & 315 hizmetkâr \\
\hline 11 & Murtaza oğlu Mehmet & 800 zıraatçı \\
\hline 12 & Mustafa oğlu Mustafa & 700 ziraatçı \\
\hline 13 & Kel Hasan oğlu Hüseyin & 800 ziraatçı \\
\hline 14 & Deli Musa oğlu Hüseyin & 150 yetim \\
\hline 15 & Cuma oğlu Mehmet & 312 irfan makulesi \\
\hline 16 & Kel Hasan oğlu Osman & $\begin{array}{l}130 \text { mecnun olup yardıma muhtaç } \\
\text { olduğu }\end{array}$ \\
\hline 17 & Usta Osman oğlu Mehmet & 288 hizmetkâr \\
\hline 18 & Tatar oğlu Musa & 300 ziraatçı \\
\hline 19 & Mal Hasan & 395 ziraatçı \\
\hline 20 & Elçi oğlu Yusuf & 523 ziraatçı \\
\hline 21 & Hamza oğlu Mehmet & 600 hizmetkâr \\
\hline 22 & Settar oğlu Mehmet & 353 hizmetkâr \\
\hline 23 & Kel Veli oğlu Veli & 460 ziraatçı \\
\hline 24 & İbiş Kethüda & 1000 ziraatçı \\
\hline 25 & Abdullah oğlu Ebu Bekir & 900 ziraatçı \\
\hline 26 & Kavlak Mehmed & 300 hizmetkâr \\
\hline 27 & Şarklı oğlu Mehmed & 333 hizmetkâr \\
\hline 28 & Hatip oğlu Ömer & 450 ziraatçı \\
\hline 29 & Şamlı Mehmed & 553 ziraatçı \\
\hline 30 & Cemal oğlu Mustafa & 300 ziraatçı \\
\hline 31 & İmama oğlu Molla Osman & 510 ziraatçı \\
\hline 32 & Yeniceli Deli ömer & 527 ziraatçı \\
\hline 33 & Hatip oğlu Hüseyin & 305 hizmetkâr \\
\hline 34 & Ankaralı oğlu Hasan'ın oğlu & 590 yetim \\
\hline 35 & Hamza oğlu Musa & 430 ziraatçı \\
\hline 36 & Kaba Osman oğlu Mehmed & 1200 ziraatçı \\
\hline 37 & Hacı Hasan & 361 ziraatçı \\
\hline 38 & Ahmed oğlu Nabi & 578 ziraatçı \\
\hline 39 & Hüseyin kethüda oğlu İbrahim & 615 ziraatçı \\
\hline 40 & Bâli oğlu Himmet & 362 ziraatçı \\
\hline 41 & Sevindi oğlu Mustafa & 520 ziraatçı \\
\hline 42 & Sevindi oğlu Süleyman & 610 ziraatçı \\
\hline 43 & $\begin{array}{l}\text { İbiş Kethüda karındaşı } \\
\text { Hüseyin }\end{array}$ & 226 irfan makulesi \\
\hline 44 & Kel Veli oğlu İbrahim & 810 ziraatçı \\
\hline
\end{tabular}




\begin{tabular}{|c|c|c|}
\hline 45 & Kara Mehmed & 997 ziraatçı \\
\hline 46 & Cingöz Ömer & 479 ziraatçı \\
\hline 47 & Kel Koçak & 404 hizmetkâr \\
\hline 48 & Deli Mehmed & 428 ziraatçı \\
\hline 49 & ŞidAhmed oğlu osman & 366 ziraatçı \\
\hline 50 & ŞidAhmed oğlu Hüseyin & 351 ziraatçı \\
\hline 51 & Kabasakal oğlu Ali & 500 ziraatçı \\
\hline 52 & İmam oğlu Osman & 213 irfan makulesi \\
\hline 53 & İmam oğlu Halil & 210 irfan makulesi \\
\hline 54 & Hasan oğlu İbrahim & 694 ziraatçı \\
\hline 55 & Hasan oğlu Osman & 600 ziraatçı \\
\hline 56 & Tatar oğlu İsa & 800 ziraatçı \\
\hline 57 & Tatar oğlu Halil & 850 ziraatçı \\
\hline 58 & Tatar oğlu Ömer & 850 ziraatçı \\
\hline 59 & İbiş oğlu Hasan & 750 ziraatçı \\
\hline 60 & Çavuş oğlu Hasan & 1000 ziraatçı \\
\hline 61 & $\begin{array}{l}\text { Ebu Bekir kethüda oğlu } \\
\text { Hüseyin }\end{array}$ & 1000 ziraatçı \\
\hline 62 & Tatar Oğlu Osman & 516 ziraatçı \\
\hline 63 & Tatar oğlu Abdullah & 200 hizmetkâr \\
\hline 64 & Danacının oğlu Veli & 628 ziraatçı \\
\hline 65 & Danacının oğlu Yusuf & 1100 ziraatçı \\
\hline 66 & Danacının oğlu Mustafa & 1060 ziraatçı \\
\hline 67 & Molla Hüseyin oğlu Veli & 200 hizmetkâr \\
\hline 68 & Çalab oğlu Hüseyin & 464 ziraatçı \\
\hline 69 & Ramazan oğlu Hüseyin & 435 ziraatçı \\
\hline 70 & Ramazan oğlu Ahmed & 350 ziraatçı \\
\hline 71 & Çolak Hasan & 460 ziraatçı \\
\hline 72 & Mal Hasan oğlu Ahmed & 270 hizmetkâr \\
\hline 73 & Hacı Halil oğlu mehmed & 565 ziraatçı \\
\hline 74 & Hacı halil oğlu Mustafa & 548 ziraatçı \\
\hline 75 & Hacı Halil oğlu Süleyman & 255 irfan makulesi \\
\hline 76 & Hacı halil oğlu Sabi Halil & 58 yetim \\
\hline 77 & Solak oğlu Ömer & 600 ziraatçı \\
\hline 78 & Mahmud Koca & 40 hasta \\
\hline 79 & Çakır oğlu süleyman & 800 ziraatçı \\
\hline 80 & Sabık İmam Ali Efendi & - \\
\hline 81 & Kel Veli oğlu Ömer & 50 fakir olduğu kayıtlı \\
\hline 82 & Türab oğlu Mahmud & Emlak ve arazisi yok \\
\hline 83 & Hamza'nın oğlu Ömer & 316 ziraatçı \\
\hline 84 & Turhan oğlu süleyman & Asker olduğu \\
\hline
\end{tabular}

\section{EYNE GAZİLÜ KARYESİ (VILLAGE OF EYNE GAZİLÜ)}

\subsection{Nüfus (Population)}

Eyne Gazilü Karyesinin nüfusu ile ilgili en eski bilgi 1530 tarihine ait bilgidir. Anllan tarihte Eyne Gazilü cemaatinin 22 nefer ile Bozok bölgesine yerleştiği bilinmektedir. ${ }^{24} 1556$ 'da Akdağ Kazasına tabi Gedik Nahiyesinin Uzun Kışla karyesinde 51 nefer ile ikamet eden

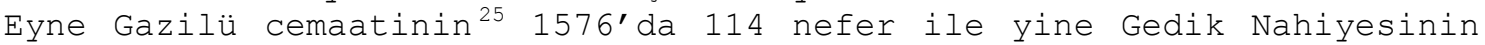
Uzun kışla karyesine gelip ikamet ettiği anlaşılmaktadır. Belgede Eyne Gazilü cemaati hakkında şu bilgiler verilmektedir. Mezkûrân diyar-ı Acemden muhaceret itmiş ehl-i ilm pâdişah-ı âlem-penâh hazretlerinin duacısı olmağın âvarız-ı divani ve tekâlif-i örfiye ve rüsûmat ve

\footnotetext{
$24 \mathrm{BOA}, \mathrm{TD}, 155, \mathrm{~S} .163$.

25 BOA, TD, 315, S. 550 .
} 
aded-i ağnâmdan emin olmak üzere kaydedilmişlerdir. ${ }^{26}$ Anılan cemaatin 1845 yılına ait temettuat kayıtlarında 156 hane ile Kırıkkale il bölgesine yerleşiği anlaşılmaktadır. Kayıtlarda Ankara Eyaleti mülhakatından Ankara Sancağı dahilinde kâin ma'den-i hümayuna merbût Dinek Keskini karyesine tabi Eyne Gazilü karyesinde mukîm ahalinin emlak arazi ve temettuatlarını mübeyyin defterdir. İbaresi yer almaktadır. ${ }^{27}$ "hane x 5+ mücerred" ${ }^{28}$ formülü dikkate alınacak olursa anılan tarihte köyün toplam nüfusunun yaklaşık olarak 780 nefer olduğu anlaşılmaktadır. ${ }^{29}$ Günümüzde Eyne Gazilü cemaatine mensup olanların Delice ilçesinin Kuzeyyurt köyünde ikamet etmekte olduğu bilinmektedir.

Tablo 14. Eyne Gazilü Karyesinde 1530-1845 yıllarındaki tahmini nüfus

(Table 14. Estimated population in Gazilü Village during 1530-1845)

\begin{tabular}{|c|r|}
\hline Ylllar & Tahmini Nüfus \\
\hline 1530 & 22 Nefer \\
\hline 1556 & 51 Nefer \\
\hline 1576 & 114 Nefer \\
\hline 1845 & 780 Nefer \\
\hline 2007 & \\
\hline
\end{tabular}

\section{2. Şahıs Adları ve Kullanılan Lakaplar} (Person Names and Used Nicknames)

Eyne Gazilü köyüne ait 680 numaralı temettüat defterinde hane reislerinin isimleri babalarını adları ve lakaplarıyla birlikte yazılmıştır. Bu nedenle köyde yaygın olarak kullanılan baba ve oğul isimlerini tespit etmek mümkün olmuştur. Tablo 15'de yer alan İsimler incelendiğinde Eyne Gazilü karyesinde Karacalı karyesinde olduğu gibi Peygamber ve onun ehl-i beyti başta olmak üzere daha çok Arapça kökenli isimlerin olduğu görülmektedir. Birinci sırada Ali ismi gelmektedir. Ali ismi toplam isimlerin o8.48'initeşkil etmektedir. İkinci sırayı ⒎2 ile Mustafa ismi almaktadır. Hasan ismi ise $\% 6.6$ ile üçüncü sırada yer almaktadır. Tabloda zikredilen isimler arasında Sevindik, Murtaza, Bekdaş, Memiş, Emir isimleri o dönemde yörede kullanılan ender isimler olarak karşımıza çıkmaktadır.

\footnotetext{
$26 \mathrm{BOA}, \mathrm{TD}, 30, \mathrm{~S} .172 / \mathrm{a}$

$27 \mathrm{BOA}, \mathrm{ML}$ VRD. TMT, $680 . \mathrm{s} .1$

28 Bu hesaplamä̈. Lütfi Barkan'ın genel nüfusu bulmak için en çok kullanılan yöntem olan

"hâne x 5" formülünden yola çıkılarak yapılmıştır. "Tarihî Demografi Araştırmaları ve

Osmanlı Tarihi", Türkiyat Mecmuası, C X, İstanbul, 1953, s.12 (1-26)

29 BOA, ML VRD.TMT, 680.s.1-65
} 
Metin, $R$.

Humanities Sciences (NWSAHS), 4C0214, 2017; 12(1): 9-34.

Tablo 15. Eyne Gazilü Karyesinde kullanılan şahıs isimleri

(Table 15. Used person names in Eyne Gazilü village)

\begin{tabular}{|c|c|c|}
\hline İsim & Sayı & $\frac{\circ}{0}$ \\
\hline Ali & 14 & 8.48 \\
\hline Mustafa & 12 & 7.2 \\
\hline Hasan & 11 & 6.6 \\
\hline Hüseyin & 10 & 6.06 \\
\hline Veli & 10 & 6.06 \\
\hline Mehmed & 10 & 6.06 \\
\hline Süleyman & 8 & 4.8 \\
\hline Osman & 7 & 4.2 \\
\hline İbrahim & 6 & 3.6 \\
\hline Ömer & 6 & 3.6 \\
\hline Halil & 5 & 3.03 \\
\hline Hamza & 5 & 3.03 \\
\hline Bekir & 4 & 2.4 \\
\hline Gani & 4 & 2.4 \\
\hline Haydar & 4 & 2.4 \\
\hline$\dot{\text { İsmail }}$ & 3 & 1.8 \\
\hline Gaffar & 3 & 1.8 \\
\hline Ahmed & 3 & 1.8 \\
\hline Hüsnü & 2 & 1.2 \\
\hline Yusuf & 2 & 1.2 \\
\hline İlyas & 2 & 1.2 \\
\hline Habib & 2 & 1.2 \\
\hline İbiş & 2 & 1.2 \\
\hline Yakub & 2 & 1.2 \\
\hline Bekdaş & 2 & 1.2 \\
\hline Murtaza & 2 & 1.2 \\
\hline Ruşen & 2 & 1.2 \\
\hline Burak & 1 & 0.6 \\
\hline Musa & 1 & 0.6 \\
\hline İsa & 1 & 0.6 \\
\hline Mansur & 1 & 0.6 \\
\hline Sadık & 1 & 0.6 \\
\hline Salih & 1 & 0.6 \\
\hline Cuma & 1 & 0.6 \\
\hline Abdullah & 1 & 0.6 \\
\hline Memiş & 1 & 0.6 \\
\hline Koçu & 1 & 0.6 \\
\hline Hュzır & 1 & 0.6 \\
\hline Durmuş & 1 & 0.6 \\
\hline nuh & 1 & 0.6 \\
\hline Fazlı & 1 & 0.6 \\
\hline Zeynel & 1 & 0.6 \\
\hline Emir & 1 & 0.6 \\
\hline Satılmış & 1 & 0.6 \\
\hline Sevindik & 1 & 0.6 \\
\hline Abbas & 1 & 0.6 \\
\hline Numan & 1 & 0.6 \\
\hline Musa & 1 & 0.6 \\
\hline Cafer & 1 & 0.6 \\
\hline Toplam & 165 & 100.0 \\
\hline
\end{tabular}




\subsection{Eyne Gazilü Karyesinde Kullanılan Lakaplar (Used Nicknames in Eyne Gazilü Village)}

Eyne Gazilü karyesinde hane reislerinin toplumda tanınmasını sağlayan aile ve sülale adlarının bazıları dinî özellik taşımaktadır. Bey, molla, hacı gibi unvanların yanında babalarının meslekleri ile anılan kimselerde bulunmaktadır. Tablo 16'te yer alan deli, kör, kel, küçük, kara gibi sıfatlarla birlikte kullanılan lakaplar ise muhtemelen ailelerin geçmişten beri kullana geldikleri lakaplar olarak görülmektedir. (Tablo 16)

Tablo 16. Eyne Gazilü Karyesinde kullanılan lakaplar

(Table 16. Used nicknames in Eyne Gazilü Village)

\begin{tabular}{|l|l|l|}
\hline $\begin{array}{l}\text { Köle Murtaza oğlu Molla } \\
\text { Yusuf }\end{array}$ & Çıtak oğlu Molla Ali & Köstekli oğlu Ali \\
\hline Solak oğlu Halil & Kürt oğlu Mehmed & Gökçek oğlu Memiş \\
\hline Karaböcük oğlu Mustafa & Çil Hüseyin oğlu Hasan & Ağzı açık oğlu Halil \\
\hline Çıtak oğlu Bekir & Karabudak oğlu Hasan & Akbıyı oğlu İmail \\
\hline Kürt Veli oğlu Hasan & Abaza oğlu Cafer & Çıtak oğlu Molla Ali \\
\hline Bursalı oğlu İbrahim & Kara Çerçi oğlu Gaffar & Topal oğlu Ali \\
\hline Körükçü oğlu Hasan & Sucu oğlu Hüseyin & Çomakçı oğlu Mehmed \\
\hline Müezzin oğlu Hasan & Kel Mehmed oğlu Ali & Oruç oğlu Ali \\
\hline Karaca oğlu Bekdaş & Kirli oğlu Molla Memiş & Deli Halil oğlu Hüseyin \\
\hline Küçük Kadı oğlu Bekir Efendi & Baytar oğlu Mustafa & Karabıyık oğlu İsmail \\
\hline Şıh oğlu Mehmed & Topsakal oğlu Hasan & Kalaycı oğlu Veli \\
\hline Hacı Hüseyin oğlu Bekir & Çölmekçi oğlu Veli & Basmacl oğlu Ali \\
\hline
\end{tabular}

\subsection{Eyne Gazilü Karyesinde Mesleki Yapılanma} (Vocational Constructing in Eyne Gazilü Village)

Tablo 17'ten anlaşılacağı üzere Eyne Gazilü karyesinde yaşayan insanların 116'sı ziraat erbabı (\%74.3), 10'u ırgat (\%6.4), 5'çoban (\%3.2), 4'ü hizmetkâr (\%2.5), olarak geçimlerini sürdürmektedir. Karyenin 59 numaralı hanesinde kayıtıı olan Mehmed oğlu Osman'ın 150 kuruş bedelle köy bekçisi (kizir)olarak görev yaptığı belirtilmiştir. ${ }^{30}$ Köyün 154 numaralı hanesinde kayıtlı olan Solak oğlu Halil'in demirci esnafindan olduğu ve demircilikten 600 kuruş elde ettiği kaydedilmiştir. Belgede bu kimse için demircilik ücretinden başka bir şeyi olmadığı belirtilmiştir. ${ }^{31}$ Köyün 80 numaralı hanesinde ikamet eden Kürt Süleyman oğlu Osman Efeni'nin medrese-i kiraminândan olduğu ve 41 kuruşluk temettuatının olduğu kaydı düşülmüştür. ${ }^{32}$ Köyün 139numaralı hanesinde kayıtlı bulunan Köle Murtaza oğlu Molla Yusuf'un talebe-i ulumdan olduğu 1260 tarihi itibarıyla Budak Özü Kazasına tabi Türkeşan köyüne nakledildiği kaydı düşülmüştür. ${ }^{33}$ Köyün 42 numaralı hanesinde ikamet eden Firuz oğlu Ahmed'in hizmetkârlığa dahi gücü kuvveti olmadığı şunun bunun yardımı ile geçimini sürdürdüğü ifade edilmiştir ${ }^{34}$ (Tablo 17).

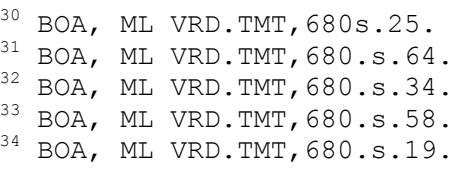


Tablo 17. Eyne Gazilü Karyesinde mesleki yapılanma

(Table 17. Vocational Constructing in Eyne Gazilü Village)

\begin{tabular}{|c|c|}
\hline Meslek Adı & Meslek Sahibi Sayısı \\
\hline Ziraat & 116 \\
\hline Muhtar & 1 \\
\hline İmam & 1 \\
\hline Hatip & 1 \\
\hline Irgat & 10 \\
\hline Hizmetkâr & 4 \\
\hline Çulhacılık & 2 \\
\hline Köy bekçisi & 1 \\
\hline Demirci Esnafından & 1 \\
\hline Çoban & 5 \\
\hline Mesleği belirtilmeyen & 14 \\
\hline Toplam & 156 \\
\hline
\end{tabular}

\subsection{Hayvancılık ve Hayvan Dağılımı \\ (Husbandry and Animal Sharing)}

Belgelerden anlaşıldığına göre 1845-1846 yıllarında tıpkı Karacalı karyesinde olduğu gibi Eyne Gazilü karyesinde yaşayan haneler de geçimlerini tarım ve hayvancılıktan sağlamakta idiler. Genel olarak süt ve süt ürünleri ihtiyaçlarını karşılamak için inek ve koyun, binek hayvanı ihtiyaçlarını karşılamak için merkep, çift sürmede faydalanabilmek için öküz kullandıkları anlaşılmaktadır. Eyne Gazilü karyesinde toplam 2276 olan hayvan varlığının büyük çoğunluğunu küçükbaş hayvanlar oluşturmaktadır. \%61.7'si küçükbaş (1405 adet), \%30.087'i büyükbaş (683 adet)adet), ⒒2'si yük ve binek hayvanım (208 adet) olarak sıralanmaktadır. Büyükbaş hayvan çeşidinde, karasığır öküzü, sağmal karasığır ineği, sağman Camus ineği ön planda yer alırken küçükbaş hayvan çeşidinde ise, koyun, keçi ve kuzu tercih edilmektedir. Binek ve yük hayvanı olarak ise merkep başta olmak üzere, kısrak beslenmektedir. (Tablo 18)

Tablo 18. Eyne Gazilü’de hane reislerinin sahip oldukları hayvan çeşitleri

(Table 18. Household heads' animal types in Eyne Gazilü Village)

\begin{tabular}{|c|c|c|c|}
\hline Hayvan çeşidi & \multirow{2}{*}{ Sayı } & \multirow{2}{*}{ Hayvan Sahibi Hane } & \multicolumn{2}{|c|}{ Toplam Hane } \\
Başına Düşen Baş
\end{tabular}

Tablo 19. Eyne Gazilü'de hane reislerinin sahip oldukları küçükbaş hayvan çeşitleri

(Table 19. Household heads' small cattle types in Eyne Gazilü Village)

\begin{tabular}{|c|c|c|c|}
\hline Küçükbaş hayvan çeşidi & Sayı & Hane & Ortalama \\
\hline Sağmal Keçi & 460 & 92 & 5.0 \\
\hline SağmalGanem & 182 & 33 & 5.5 \\
\hline Oğlak & 420 & 87 & 4.8 \\
\hline Kuzu & 130 & 25 & 5.2 \\
\hline Yoz Ganem & 88 & 28 & 3.52 \\
\hline Yoz Keçi & 125 & 33 & 3.7 \\
\hline Toplam & 1405 & 300 & \\
\hline
\end{tabular}

Eyne Gazilü'de yetiştirilen küçükbaş hayvanlar içinde koyun ve keçi türleri ön planda yer almaktadır. 1405 adet küçükbaş hayvanın 
460'ı sağmal keçi toplam 92 hanenin elinde bulunmaktadır. Sağmal ganem (koyun) 182 adet olup toplam 33 hanenin elinde bulunmaktadır. Koyun ve keçiye sahip olan hanelerin genel durumlarına bakıldığı zaman yılıık temettuat oranlarının yüksek olduğu görülmektedir. Mesela köyün 2 numaralı hanesinde kayıtlı olan Hasan Kethüda oğlu Ömer Ağa'nın 14 sağman ganemi, 8 adet sağman keçisi vardır. Bunun yanında sağman karasığır ineği, sağman camus ineği, gibi büyükbaş hayvanlara da sahip olması, yıllık gelirinin de 1205 akçeye tekabül etmesi varlıklı aileler arasında değerlendirilmesine sebeb olmuştur. 35 Köyün 52 numaralı hanesinde ikamet eden Şehirli oğlu Halil'in sadece 1 sağman keçisi ve 1 oğlağı bulunmaktadır. Yılıık gelirinin 398 kuruş olmasından da anlaşılacağı üzere varlık bakımından köyün alt gurubunda yer aldığı anlaşılmaktadır. ${ }^{36}$ Bu tür örnekleri artırmak mümkündür. Belgelerden anladığımız kadarıyla köyde gelir düzeyi yüksek ailelerin genelde küçükbaş ve büyükbaş hayvan sayılarının yüksek olduğu anlaşılmaktadır. (Tablo 19)

Tablo 20. Eyne Gazilü'de Hane Reislerinin Sahip oldukları Büyükbaş Hayvan Çeşitleri

(Table 20. Household Heads' Cattle Types in Eyne Gazilü Village)

\begin{tabular}{|l|c|c|c|}
\hline Büyükbaş Hayvan çeşidi & Sayı & Hayvan Sahibi Hane & Ortalama \\
\hline Karasığır Öküzü & 350 & 118 & 2.9 \\
\hline Sağmal İnek & 114 & 88 & 1.2 \\
\hline Sağmalcamus İneği & 5 & 6 & 0.8 \\
\hline Buzağı & 103 & 78 & 1.3 \\
\hline Düve & 32 & 34 & 0.9 \\
\hline Erkek Camus & 40 & 12 & 3.3 \\
\hline Malak & 8 & 3 & 2.6 \\
\hline Tosun & 11 & 3 & 3.6 \\
\hline Erkek Dana & 20 & 6 & 3.3 \\
\hline Toplam & 683 & 354 & \\
\hline
\end{tabular}

1844-1845 yılları arasında Eyne Gazilü karyesinde özellikle karasığır öküzü ahalinin tarım yaparken kullandığı vazgeçilmez iş gücü kaynaklarından biri durumundadır. Köyde toplam 156 haneden 118 hanede karasığır öküzüne tesadüf edilmektedir. Köyün süt ve süt ürünleri ihtiyacının sağlanmasında sağmal Karasığır ineği ve sağmal camus ineği ön planda yer almaktadır. Sağmal karasığır ineği 114 hanede yer alırken sağmal camus ineği 6 hanede bulunmaktadır. Anılan hanelerin gelir düzeyi dikkate alındığında genel ortalamanın üzerinde oldukları dikkat çekmektedir. Köyün 1 numaralı hanesinde kayıtıı olan Hatip oğlu Ömer'in büyükbaş hayvan çeşitlerinden hepsine sahip olduğu yıllık gelirini ise 1208 kuruş olduğu belgelerden anlaşılmaktadır. 37 Buna karşın köyün 84 numaralı hanesinde ikamet eden Kel Mehmed oğlu Ali'nin büyükbaş hayvanlarının bulunmadığı yılıık toplam gelirinin ise 397 akçe olduğu belgelerden anlaşılmaktadır. ${ }^{38}$ Yük ve Binek Hayvanlarına gelince; EyneGazilü'de1845 yılında toplam 208 adet yük ve binek hayvanı bulunmaktadır. Bunlardan 169 tanesi merkep, 26 tanesi kısrak, 12 tanesi katır 1 tanesi tay olmak üzere toplam 208olarak tespit edilmiştir. (Tablo 20)

\footnotetext{
BOA, ML VRD.TMT, 680.S.2.

36 BOA, ML VRD.TMT, 680.s.22.

$37 \mathrm{BOA}, \mathrm{ML}$ VRD.TMT, 680.s.2.

38 BOA, ML VRD.TMT, 680.s.36.
} 
Tablo 21. Eyne Gazilü'de hane reislerinin sahip oldukları yük ve binek hayvanı çeşitleri

(Table 21. Household heads' draught and mount animals types in Eyne Gazilü Village)

\begin{tabular}{|l|c|c|c|}
\hline Hayvan Çeşidi & Sayı & Hayvan Sahibi Hane & Ortalama \\
\hline Merkeb & 169 & 120 & 1.4 \\
\hline Kısır Kısrak & 26 & 14 & 1.8 \\
\hline Katır & 12 & 2 & 6 \\
\hline Tay & 1 & 1 & 1 \\
\hline Toplam & 208 & 137 & \\
\hline
\end{tabular}

Yük ve binek hayvanına sahip olan hanelerin geneli ziraatle iştigal eden haneler olarak kaydedilmiştir. Özellikle buğday, arpa ve pamuk üretiminin yapıldığı köyde tarladaki ürünü ambara taşımak için merkeb, en önemli yük hayvanı olarak görülmektedir. Toplam 156 hane olan köyde 120 hanede merkeb beslenmesi bu durumu net bir şekilde ifade etmektedir. (Tablo 21)

\subsection{Arazi Dağılımı ve Toprak Kullanımı (Cultivated and Planted Agricultural Fields)}

Eyne Gazilü'de 1844-1845 yılları arasında ekilebilir arazi 4989 dönüm iken gayr-ı mezru yani ekilemeyen arazi 50 dönüm olarak tespit edilmiştir. Hane reislerinin \%90.17'si (108 hane) ekilebilir tarlada buğday ve arpa tarımı ile iştigal etmektedir. ⒌7'si(108 hane) penbe (pamuk), ⒋02'si de bağcılıkla uğraşmaktadır. Daha çok ehl-i ziraat olan kimselerin buğday, arpa, pamuk ve bağcılık üretimini gerçekleştirdiği anlaşılmaktadır. Köyün 55 numaralı hanesinde ikamet eden Küçük oğlu Hasan'ın ziraat erbabı olmasına rağmen 50 dönümlük arazisini boş bıraktığı belgelerden anlaşılmaktadır. ${ }^{39}$ (Tablo 22)

Tablo 22. Eyne Gazilü'de ekili ve dikili tarım alanlarının dağılımı

(Table 22. Distribution of cultivated and planted agricultural fields in Eyne Gazilü)

\begin{tabular}{|l|c|c|c|c|}
\hline Ekilebilir Arazi Türü & Miktar (Dönüm) & Hane & Ortalama & $\frac{\circ}{\circ}$ \\
\hline Tarla (Buğday-Arpa) & 4499 & 108 & 41.6 & 90.17 \\
\hline Penbe (Pamuk) & 289 & 108 & 2.6 & 5.7 \\
\hline Bağ & 201 & 123 & 1.6 & 4.02 \\
\hline Gayr-ı Mezru Tarla & 50 & 1 & 50 & \\
\hline Toplam & 5039 & & & \\
\hline
\end{tabular}

\subsection{Gelirler (Incomes)}

\subsubsection{Tarım Gelirleri (Hasılatı) (Agricultural Incomes)}

1844-1845 yılları arasında Eyne Gazilü köyüne ait buğday ve arpa ekili tarım alanları 4499 dönüm olup 41.190 kuruş gelir elde edilmiştir. Penbe (pamuk) ekilen arazi ise 289 dönüm olup toplamda 7180 kuruş gelir elde edilmiştir. 201 dönüm bağdan ise 10750 kuruş gelir sağlanmıştır. (Tablo 23)

Tablo 23. Eyne Gazilü'de ekili-dikili tarım alanlarının hasılatı

(Tablo 23. Cultivated agricultural land revenue in Eyne Gazilü)

\begin{tabular}{|l|c|c|c|}
\hline Ekilebilir Arazi Türü & Miktar (Kuruş) & Miktar (Dönüm) & Ort. \\
\hline Tarla (Buğday-Arpa) & 41.190 & 4499 & 9.1 \\
\hline Penbe (Pamuk) & 7.180 & 289 & 24.8 \\
\hline Bağ & 10.750 & 201 & 53.4 \\
\hline Toplam & 59.120 & & \\
\hline
\end{tabular}

39 BOA, ML VRD.TMT, 680. S.24. 
Temettuat defterlerinde köylüden alınan hububat öşrü verilerinden üretilen hububatların ne kadar olduğu tespit edilebilir. Öşür bölgelere göre değişmekle birlikte ortalama her ürün üzerinden olo oranında alınmaktadır. Bu nedenle Tablo 22' de vergiye esas olan toplam kilenin 10 katı alınarak toplam hububat üretimi tespit edilmeye çalışılmıştır.

Tablo 24. Eyne Gazilü'de üretilen toplam hububat miktarı Tablo 24. Total amount of grain in Eyne Gazilü)

\begin{tabular}{|l|c|c|c|}
\hline Ekilebilir Arazi Türü & Kile & Kile x 10 & \multicolumn{1}{c|}{ Kg } \\
\hline Hınta (Buğday) & 280 & 2800 & 7.183 \\
\hline Şair (Arpa) & 147 & 1470 & 3.711 \\
\hline Penbe (Pamuk) & 154 kıyye & 1540 & 3.951 \\
\hline Pekmez & 902 kıyye & 9020 & 23.141 \\
\hline
\end{tabular}

\subsubsection{Hayvancılık Hasılatı (Agricultural Incomes)}

Eyne Gazilü'de tarımdan sonra ikinci sırada yer alan hayvancılık gelirleri 7722 kuruştur. Hayvancılık hasılatı büyükbaş, küçükbaş ve yük-binek olarak üç grupta incelenebilir. Tablo 25'deki veriler incelendiğinde görüleceği üzere, hayvancılık hasılatında ilk sırayı küçükbaş hayvanlar almaktadır. Bu hayvanlardan fiyatlandırılan sağmal koyun, sağmal keçi, you ganem (koyun) ve yoz keçinin toplam fiyatı 4147 kuruştur. İkinci sırada büyükbaş hayvanlar yer almaktadır. Bu hayvanlardan sağmal karasığır ineği ve sağmal camus ineğinin toplam fiyatı 3575 kuruş olarak belirlenmiştir. Üçüncü olarak yük-binek hayvanları gelmektedir. Bu hayvanlardan merkeb ve kısrak döllü olmadığı için fiyatlandırmaya tabi tutulmamıştır.

Tablo 25. Eyne Gazilü'de hayvancılık hasılatı dağılımı (Table 25. Distribution of Husbandry Income in Eyne Gazilü)

\begin{tabular}{|l|c|c|c|}
\hline Hayvan Çeşidi & Hasılat Miktarı Kuruş & Hayvan Sahibi Hane & Ort. \\
\hline Küçükbaş & 4147 & 300 & 13.8 \\
\hline Büyükbaş & 3575 & 354 & 10.09 \\
\hline Yük-Binek & - & 137 & - \\
\hline Toplam Sayı & 7722 & & \\
\hline
\end{tabular}

\subsubsection{Meslek Hasılatı (Vocational Incomes)}

Meslek gelirleri toplamda 3905 kuruş olarak tespit edilmiştir. Bu toplama meslek olarak kaydedilen imam, çulhacı, demirci, ırgatlık, amele, çobanlık, köy bekçisi( kizir) gibi meslekler dahildir. Köyün büyük çoğunluğu "erbâb-ı ziraat" olarak kaydedilmiştir. Meslek hasılatına "ebab-ı ziraat" gurubu dahil edilmemiştir. Köyün 59 numarasında kayıtlı olan ve kizir (köy bekçisi) olarak görev yapan Mahmut oğlu Osman'ın bu işten yılıık kazancının 395 kuruş olduğu kaydedilmiştir. ${ }^{41}$ Köyün 154 numarasında kayıtlı Solak oğlu Haliı'in demirci esnafından olduğu ve bu meslekten yılda 600 kuruş kazandığı belgelerden anlaşılmaktadır. ${ }^{42}$ Köyün 93 numaralı hanesinde kayıtlı olan Çakır Ahmed oğlu Ahmed'in çobanlık mesleği ile iştigal ettiği bu meslekten yılda 250 kuruşluk bir gelir elde ettiği kaydedilmiştir. ${ }^{43}$

\footnotetext{
$40 \mathrm{Bu}$ çalışmada hesaplamalar yapılırken buğday, penbe (pamuk) ve pekmez için 1 kile=25, $656 \mathrm{~kg}$.; arpa için isel kile=22,25kg. olarak alınmıştır.

41 BOA, ML VRD.TMT, 680.s.25.

42 BOA, ML VRD.TMT, 680.s.64.

43 BOA, ML VRD.TMT, 680.s.40.
} 


\subsubsection{Vergü-yi Mahsusa}

1844-1845 yılları arasında Eyne Gazilü'de tespit ettiğimize göre toplam vergü-yi mahsusa bedeli 20.095 kuruştur. Vergi-yi mahsusa olarak en düşük vergi 33 kuruş, en yüksek vergi ise 261 kuruştur. Köyün 59 numaralı hanesinde kayıtlı olan Mahmud oğlu Osman'ın köyde kizir (köy bekçisi) olarak görev yaptığı ve vergü-yi mahsusa bedelinin ise 33 kuruş olarak kaydedildiği belgelerden anlaşılmaktadır. ${ }^{44}$ Köyün 21 numaralı hanesinde kayıtlı olan Gani oğlu Halil'in yllık ödediği vergü-yi mahsusa bedeli ise 319.5 kuruş olarak belirtilmiştir. ${ }^{45}$

Tablo 26. Eyne Gazilü’de hane reislerinin verdiği toplam öşür ve aded-i ağnam vergisi

(Table 26. Total Amount of Öşür and Aded-i Ağnam Taxes given by Household Heads in Eyne Gazilü)

\begin{tabular}{|c|c|c|c|c|}
\hline $\begin{array}{l}\text { Ekili Tarım Öşrü ve } \\
\text { Aded-i Ağnam Vergisi }\end{array}$ & $\begin{array}{l}\text { Miktar } \\
\text { (Kuruş) }\end{array}$ & Hane & Ort. & $\frac{\circ}{0}$ \\
\hline Hınta (Buğday) & 3333 & 116 & 28.7 & 53.2 \\
\hline Şair (Arpa) & 1150 & 116 & 9.9 & 18.3 \\
\hline Penbe (Pamuk) & 752 & 118 & 6.3 & 12.0 \\
\hline Bă̆ & 45 & 8 & 5.6 & 0.7 \\
\hline Aded-İ Ağnam & 82 & 45 & 1.8 & 1.3 \\
\hline Pekmez & 902 & 124 & 7.2 & 14.3 \\
\hline Toplam & 6264 & & & \\
\hline
\end{tabular}

Toplu olarak verdiğimiz vergi türlerinden ekili tarım üzerinden alınan öşür vergisi ile alâkalı olarak hınta (buğday) 53.2 ile ilk sırada gelmektedir. Onu o18.3 ile şair (arpa), \%14.3 ile pekmez ve \%12 ile penbe (pamuk) izlemektedir. Ağnam vergisi \%1.3 bağ vergisi ise o0.7 olarak tespit edilmiştir. Bu verilerden anlaşıldığına göre Eyne Gazilü köyünde tıpkı Balışeyh'te olduğu gibi en düşük vergi çeşidi ağnam olurken en yüksek vergi çeşidi hınta (buğday) olarak görülmektedir (Tablo 26).

44 BOA, ML VRD.TMT, 680.s.25.

45 BOA, ML VRD.TMT, 680.s.10. 
Tablo 27. Eyne Gazilü'de ikamet eden kimselerin hane sırasına göre toplam temettuatları

(Table 27. Persons' temettuats according to household sequencing who resident in Eyne Gazilï)

\begin{tabular}{|c|c|c|}
\hline Hane No & Kişi Adı & Temettuat Toplamı Kuruş \\
\hline 1 & Hatip oğlu Ömer & 1208 \\
\hline 2 & Hasan Kethüda oğlu Ömer Ağa & 1205 \\
\hline 3 & Küçük Kadı Oğlu Bekir Efendi & 457 \\
\hline 4 & Kaba oğlu İbrahim & 228 \\
\hline 5 & Kaba oğlu Mustafa & 250 \\
\hline 6 & Karamanlıoğlu Molla Mustafa & 230 \\
\hline 7 & Kürekçi oğlu Habib & 354 \\
\hline 8 & Kürekçi oğlu süleyman & 418 \\
\hline 9 & Pervane oğlu Ahmed & 586 \\
\hline 10 & Pervane oğlu Ruşen & 557 \\
\hline 11 & Pervane oğlu Habib & 215 \\
\hline 12 & Arzu oğlu Ahmed & 534 \\
\hline 13 & Hüsnü oğlu Hüseyin & 501 \\
\hline 14 & Pervane oğlu İsa & 438 \\
\hline 15 & Kürt Ali oğlu Veli & 516 \\
\hline 16 & Kürt Ali oğlu Hasan & 511 \\
\hline 17 & Burak oğlu Ali & 914 \\
\hline 18 & Kürt Musa oğlu Mansur & 857 \\
\hline 19 & Sadık oğlu Bekir & 724 \\
\hline 20 & Gani oğlu Gani & 430 \\
\hline 21 & Gani oğlu Halil & 1637 \\
\hline 22 & Haydar oğlu Ömer & 873 \\
\hline 23 & Köyce oğlu Mehmed & 723 \\
\hline 24 & Köyce oğlu Salih & 520 \\
\hline 25 & Kadızâde Veli oğlu Veli & 360 \\
\hline 26 & Yüncü oğlu İbrahim & Nakil Dervişân \\
\hline 27 & Hamza oğlu Hüseyin & 1218 \\
\hline 28 & Hamza oğlu Hamza & Sehven yazılmış \\
\hline 29 & Ökben oğlu Mehmed & 805 \\
\hline 30 & Baytar oğlu Mustafa & Talebe-i ulum -- \\
\hline 31 & Hindi oğlu Mehmed & 230 \\
\hline 32 & Gani oğlu Salih & 1358 \\
\hline 33 & Gani oğlu Osman & 1174 \\
\hline 34 & Çorçor oğlu Hasan & 466 \\
\hline 35 & Demirci oğlu Mustafa & 562 \\
\hline 36 & Demirci oğlu Halil & 347 \\
\hline 37 & Demirci oğlu Cuma & 1311 \\
\hline 38 & Demirci oğlu Abdullah & 415 \\
\hline 39 & Sekban oğlu İbrahim & 1038 \\
\hline 40 & Karabıyık oğlu İsmail & 744 \\
\hline 41 & Koca oğlu Hasan & 300 \\
\hline 42 & Firuz oğlu Mustafa & $\begin{array}{l}\text { Şunun bunun ianesiyle } \\
\text { geçindiği }\end{array}$ \\
\hline 43 & Sekban oğlu Mustafa & 521 \\
\hline 44 & Şıh oğlu Mehmed & 640 \\
\hline 45 & Şıh oğlu İbrahim & 460 \\
\hline 46 & Dede oğlu Halil & 500 \\
\hline 47 & Topsakal oğlu Hasan & 250 \\
\hline 48 & Koçu oğlu Hüseyin & 275 \\
\hline 49 & Koçu oğlu Mehmed & 355 \\
\hline 50 & Aşkın oğlu Memiş & 358 \\
\hline
\end{tabular}


Metin, $R$.

Humanities Sciences (NWSAHS), 4C0214, 2017; 12(1): 9-34.

\begin{tabular}{|c|c|c|}
\hline 51 & Hatip oglu İbiş & 478 \\
\hline 52 & Şehirli oğlu Halil & 398 \\
\hline 53 & Kalaycı oğlu Veli & 547 \\
\hline 54 & Hacı Hüseyin oğlu Bekir & 776 \\
\hline 55 & Küçük oğlu Hasan & 322 \\
\hline 56 & Konakçı oğlu Ömer & 406 \\
\hline 57 & Yılan oğlu Hacı Ömer & 872 \\
\hline 58 & Öksüz oğlu Hüseyin & 428 \\
\hline 59 & Mahmud oğlu Osman & 395 \\
\hline 60 & Mahmud oğlu Ömer & 252 \\
\hline 61 & Cennetin oğlu Süleyman & 258 \\
\hline 62 & Kürt Süleyman oğlu İsmail & 332 \\
\hline 63 & Çölmekçi oğlu Veli & 544 \\
\hline 64 & Dıraz oğlu İbrahim & 746 \\
\hline 65 & Basmacı oğlu İbrahim & 510 \\
\hline 66 & Basmacı oğlu Ali & 369 \\
\hline 67 & İlyas oğlu $\dot{I} b i s ̧$ & 503 \\
\hline 68 & Hızır oğlu Mehmed & 455 \\
\hline 69 & İbiş oğlu Ahmed & 290 \\
\hline 70 & Çıtak oğlu Hasan & Vefat \\
\hline 71 & Hatip oglu Süleyman & 939 \\
\hline 72 & Şehirli oğlu Osman & 392 \\
\hline 73 & - & \\
\hline 74 & - & \\
\hline 75 & - & \\
\hline 76 & - & \\
\hline 77 & Kalaycı oğlu Mehmed & 388 \\
\hline 78 & Şıh veled oğlu İsmail & 1234 \\
\hline 79 & Mahmud oğlu Mustafa & 225 \\
\hline 80 & $\begin{array}{c}\text { Kürt Süleyman oğlu Osman } \\
\text { Efendi }\end{array}$ & Medrese-i kirâminandan \\
\hline 81 & Çölmekçi oğlu Osman & 329 \\
\hline 82 & Müezzin oğlu Hasan & 425 \\
\hline 83 & Durmuş oğlu Yusuf & 441 \\
\hline 84 & Kel Mehmed oğlu Ali & 397 \\
\hline 85 & Topal Hüseyin oğlu Halil & 110 \\
\hline 86 & Oruç oğlu Ali & 446 \\
\hline 87 & Oruç oğlu Mehmed & 732 \\
\hline 88 & Çıbıklı oğlu Hüseyin & 330 \\
\hline 89 & Oruç oğlu Hamza & 407 \\
\hline 90 & İlyas oğlu zâde Mustafa & 704 \\
\hline 91 & Durmuş oğlu Nuh & 639 \\
\hline 92 & İlyas oğlu Hasan & 430 \\
\hline 93 & Çakır Ahmed oğlu Ahmed & 325 \\
\hline 94 & Ali oğlu Ömer & 451 \\
\hline 95 & Deli Halil oğlu Mehmed & 811 \\
\hline 96 & Emir Osman oğlu Mahmud & 1388 \\
\hline 97 & Kirli oğlu Veli & 345 \\
\hline 98 & Sarar oğlu Mustafa & 504 \\
\hline 99 & Hanefi oğlu Mustafa & 560 \\
\hline 100 & Çeriğ oğlu Ali & 839 \\
\hline 101 & Deli Halil oğlu Hüseyin & 836 \\
\hline 102 & Emir oğlu Satılmış & 232 \\
\hline 103 & Derviş oğlu Yakub & 597 \\
\hline 104 & Kürt Ali Ağası oğlu süleyman & 438 \\
\hline 105 & Karaca oğlu Bekdaş & 735 \\
\hline
\end{tabular}


Metin, $R$.

Humanities Sciences (NWSAHS), 4C0214, 2017; 12(1): 9-34.

\begin{tabular}{|c|c|c|}
\hline 106 & Kirli oğlu Molla Memiş & 450 \\
\hline 107 & Sevindik oğlu Hasan & 622 \\
\hline 108 & Çomakçı oğlu Mehmed & 483 \\
\hline 109 & Karaca Kızı oğlu Hüseyin & 445 \\
\hline 110 & Çeriğ oğlu Halil & 477 \\
\hline 111 & Sucu oğlu Ahmed & 455 \\
\hline 112 & Bekdaş oğlu Hüseyin & 478 \\
\hline 113 & Sucu oğlu Hüseyin & 549 \\
\hline 114 & Sucu oğlu Mehmed & 739 \\
\hline 115 & Körükçü oğlu Hasan & 220 \\
\hline 116 & Çitke oğlu Mustafa Efendi & 527 \\
\hline 117 & Gaffar Kahya oğlu süleyman & 498 \\
\hline 118 & Gaffar Kethüda oğlu Ali & 651 \\
\hline 119 & Bursalı oğlu Abbas & 413 \\
\hline 120 & Haydarın oğlu Mustafa & 370 \\
\hline 121 & Kara Çerçi oğlu Gaffar & 406 \\
\hline 122 & Topal oğlu Ali & 416 \\
\hline 123 & Murtaza Ağa oğlu Mehmed & 814 \\
\hline 124 & Bursalı oğlu i̇brahim & 156 \\
\hline 125 & Fazlı oğlu Ali & 829 \\
\hline 126 & Veli Dede oğlu Hüseyin & 221 \\
\hline 127 & Çil Hüseyin oğlu Zeynel & 527 \\
\hline 128 & Ali Pir oğlu Veli & 416 \\
\hline 129 & Kösdekli oğlu Ali & 672 \\
\hline 130 & Esirzâde oğlu $\dot{I} l y a s$ & 712 \\
\hline 131 & Çıtak oğlu Molla Ali & 787 \\
\hline 132 & Numan oğlu mustafa & 761 \\
\hline 133 & Kürt Musa oğlu Veli & 420 \\
\hline 134 & Hayta Yakub oğlu Halil & 961 \\
\hline 135 & Kaba oğlan oğlu İsmail & 428 \\
\hline 136 & Kürt veli oğlu Hasan & 210 \\
\hline 137 & Abaza oğlu Cafer & 309 \\
\hline 138 & Akbıyık oğlu İsmail & 336 \\
\hline 139 & $\begin{array}{c}\text { Köle Murtaza oğlu Molla } \\
\text { Yusuf }\end{array}$ & $\begin{array}{l}\text { Budak özü Türrkeşan köyüne } \\
\text { nakil }\end{array}$ \\
\hline 140 & Hindi oğlu Ali & 412 \\
\hline 141 & Veli Dede oğlu Ali & 412 \\
\hline 142 & Kara Budak oğlu Hasan & 942 \\
\hline 143 & Emirzâde oğlu Mehmed & 394 \\
\hline 144 & Kalkal oğlu Ali & 645 \\
\hline 145 & Çıtak oğlu Bekir & 428 \\
\hline 146 & Emrullah oğlu Ali & 260 \\
\hline 147 & Hamza oğlu Murtaza & 455 \\
\hline 148 & Ağzıaçık oğlu Halil & 220 \\
\hline 149 & Çil Hüseyin oğlu Hasan & 1040 \\
\hline 150 & Kara Böcük oğlu Mustafa & 130 \\
\hline 151 & Gökçek oğlu Memiş & Tahrir esnasında vefat \\
\hline 152 & Kalaycı oğlu Halil & 50 \\
\hline 153 & Mehmed oğlu Musa & 100 \\
\hline 154 & Solak oğlu Halil & 600 \\
\hline 155 & Dede oğlu Musa & 237 \\
\hline 156 & Kürt oğlu Mehmed & 446 \\
\hline
\end{tabular}




\section{SONUÇ (CONCLUSION)}

Karacalı ve Eyne Gazilü köyleri ile ilgili en eski bilgileri XVI. Yüzyılın ilk ve son çeyreğine doğru bulmak mümkündür. 1578-1579 tarihine ait bilgilerde yörük cemaatlerinden olan Karacalu/Karacalar cemaati 54 hane ve 68 mücerred ile Kırıkkale ìl bölgesine yerleşmiştir. 761 numaralı temettuat defterinden tespit ettiğimiz kadarı ile 1844-1845 yılları arasında Karacalı karyesinin 84 haneye tekâbül eden 420 neferlik nüfusu kayıt altına alınmıştır. 2007 yılı adrese dayalı nüfus tespitine göre ise anılan köyde 365 kişi bulunmaktadır.

Eyne Gazilü Karyesinin nüfusu ile ilgili en eski bilgi 1530 tarihine ait bilgidir. Anllan tarihte Eyne Gazilü cematinin 22 nefer ile Bozok bölgesine yerleştiği bilinmektedir. 1556'da Akdağ Kazasına tabi Gedik Nahiyesinin Uzun Kışla karyesinde 51 nefer ile ikamet eden Eyne Gazilü cemaatinin 1576'da 114 nefer ile yine Gedik Nahiyesinin Uzun kışla karyesinde ikamet ettiği anlaşılmaktadır. 1556-1576 yılları arasında anılan karyede o100'ün üzerinde bir nüfus artışının olduğu gözlemlenmektedir. 1845 yılına ait 680 numaralı temettuat defterinde ise Eyne Gazilü cemaatinin 156 hane ile Kırıkkale ìl bölgesinde köy kurduğu anlaşılmaktadır. Hane x 5 +mücerred ${ }^{46}$ formülü dikkate alınacak olursa anılan tarihte köyün toplam nüfusunun yaklaşık olarak 780 nefer olduğu anlaşılmaktadır.

Karacalı ve Eyne Gazilü karyelerinin iktisadi ve sosyal yapısı incelendiğinde her iki yerleşim birimi de de ana geçim kaynağının tarım ve hayvancılık olduğu görülmektedir. Her iki köyde zirâิ üretimin en önemli kısmını ekili tarım alanları oluşturmaktadır. Ekili tarım alanları bakımından anılan her iki köyde de başta buğday olmak üzere arpa ve penbe (pamuk) üretilmektedir. Karacalı karyesinde 2671 dönüm ekilebilir araziden toplam 28311 kuruş gelir elde edilirken Eyne Gazilü karyesinde 5039 dönüm olan ekilebilir araziden 59.120 kuruş gelir elde edilmiştir.

Hayvancllıkta ise her iki karyede de küçükbaş, büyükbaş ile yük ve binek hayvanlarının gündelik ihtiyaçlar ölçüsünde beslendiği görülmektedir. Karacalı'da toplam 400 olan hayvan varlığının büyük çoğunluğunu küçükbaş hayvanlar oluşturmaktadır. 54'ü küçükbaş (216 adet), 27.5'i büyükbaş (110 adet) ve o15.5'i yük ve binek (74 adet) hayvanı olarak sıralanmaktadır. Küçükbaş hayvan çeşidinde, koyun, keçi, kuzu ve oğlak beslenirken büyükbaş hayvan çeşidinde, karasığır öküzü, sağmal inek ve camus ön planda yer almıştır. Binek ve yük hayvanı olarak ise merkep beslenmektedir.

Eyne Gazilü karyesinde toplam 2276 olan hayvan varlığının büyük çoğunluğunu küçükbaş hayvanlar oluşturmaktadır. \%61.7'si küçükbaş (1405 adet), 30.087'i büyükbaş (683 adet), \%11.2'si yük ve binek hayvanım (208 adet) olarak sıralanmaktadır. Büyükbaş hayvan çeşidinde, karasığır öküzü, sağmal karasığır ineği, sağman Camus ineği ön planda yer alırken küçükbaş hayvan çeşidinde ise, koyun, keçi ve kuzu tercih edilmektedir. Binek ve yük hayvanı olarak ise merkep başta olmak üzere, kısrak beslenmektedir.

1844-1845 yılları arasında bu iki karyeye atfedilen öşür ve adedi ağnam vergilerine gelince; Karacalı karyesinde toplam 3.241 kuruş olan öşür ve aded-i ağnam vergisi Eyne Gazilü karyesinde 6.264 kuruş olarak tespit edilmiştir.

Miktarı liva ölçeğinde belirlenen ve livaya bağlı kazalar arasında paylaştırılan vergi-yi mahsusa bedeli olarak Karacalı'da tespit ettiğimize göre toplam vergi-yi mahsusa bedeli 18.029 kuruştur.

\footnotetext{
${ }^{46} \mathrm{Bu}$ hesaplama Ö. Lütfi Barkan'ın genel nüfusu bulmak için en çok kullanılan yöntem olan "hâne x 5" formülünden yola çıkılarak yapılmıştır. "Tarihî Demografi Araştırmaları ve Osmanlı Tarihi", Türkiyat Mecmuası, C X, İstanbul, 1953, s.12 (1-26)
} 
Eyne Gazilü'de tespit ettiğimize göre ise toplam vergi-yi mahsusa bedeli 20.095 kuruştur. Sosyal yapı olarak bakıldığında her iki karyede de kullanılan lakaplardan aile ve sülale adlarının çoğunun Molla, Hatip, müezzin, Şıh, Hacı gibi dinî özellik taşı̆̆ı görülmektedir. Sonuç olarak, temettuat defterleri ağırlıklı olarak yapmış olduğumuz bu çalışma ile 1844-1845 yılları arasında, bugün Kırıkkale ilimizin iki şirin yerleşim yeri olan Karacalı ve Eyne Gazilü köylerinin sosyo-ekonomik durumları ortaya konulmaya çalışılmıştır. Bu vesile ile ileride yapılacak çalışmalara bir nebzede olsa katkı sunmak hedeflenmiştir.

\section{KAYNAKLAR (REFERENCES)}

\section{Arşiv Belgeleri (Archive Documents)}

- BOA, ML VRD.TMT, 680

- BOA, ML VRD.TMT, 761

- BOA, TD, 155.

- BOA, TD, 315.

- BOA, TD, 30.

\section{Makale ve Kitaplar (Article and Books)}

- Barkan, Ö.L., (1953). Tarihî demografi araştırmaları ve Osmanlı tarihi (Cilt: X). İstanbul: Türkiyat Mecmuası.

- Devellioğlu, F., (1996). "Temettü'-Temettüat", Osmanlıca-Türkçe Ansiklopedik Lügat (13. Baskı.) Ankara: Aydın Kitabevi Yayıları.

- Gül, A., (2009). Temettuat Defterlerine Göre Pasinler'in (Hasankale) Sosyal ve EkonomikYapısı. Karadeniz Araştırmaları, $6(23): 77-98$.

- Güran, T., (2000). "19. Yüzyıl Temettüat Tahrirleri", H. İnalcık, \& Ş. Pamuk (Dü) içinde: Osmanlı Devleti'nde Bilgi ve İstatistik, Ankara: T.C. Başbakanlık Devlet İstatistik Enstitüsü, 73-94.

- Kankal, A., (2009). XVI. Yüzyılda Çankırı. Çankırı: Çankırı Belediyesi Kültür Yayınları.

- Kütükoğlu, M., (1995). Osmanlı Sosyal ve İktisadî Tarihi Kaynaklarından Temettü Defterleri. Belleten, Cilt:LIX, Sayı:225, ss:395-412.

- Özer, İ., (2000). Temettuat Defterlerinde Somuncu Babanın Nesebi (1844),Akademik Araştırmalar Dergisi, 4-5:593-609.

- Öztürk, S., (2000). Temettuat Tahrirleri. Akademik Araştırmalar Dergisi Osmanlı Özel Sayısı: Sayı:4-5, ss:537-591.

- Serin, M., (1998). Osmanlı Arşivi'nde Bulunan Temettuat Defterleri. T.C. Başbakanlık I.Millî Arşiv Şûrası (20-21 Nisan 1998) Tebliğler Tartışmalar, Ankara: T.C. Devlet Arşivleri Genel Müdürlüğui Yayınlar. 
EK 1:

TEMETTUAT DEFTERLERİNDEN ÖRNEKLER

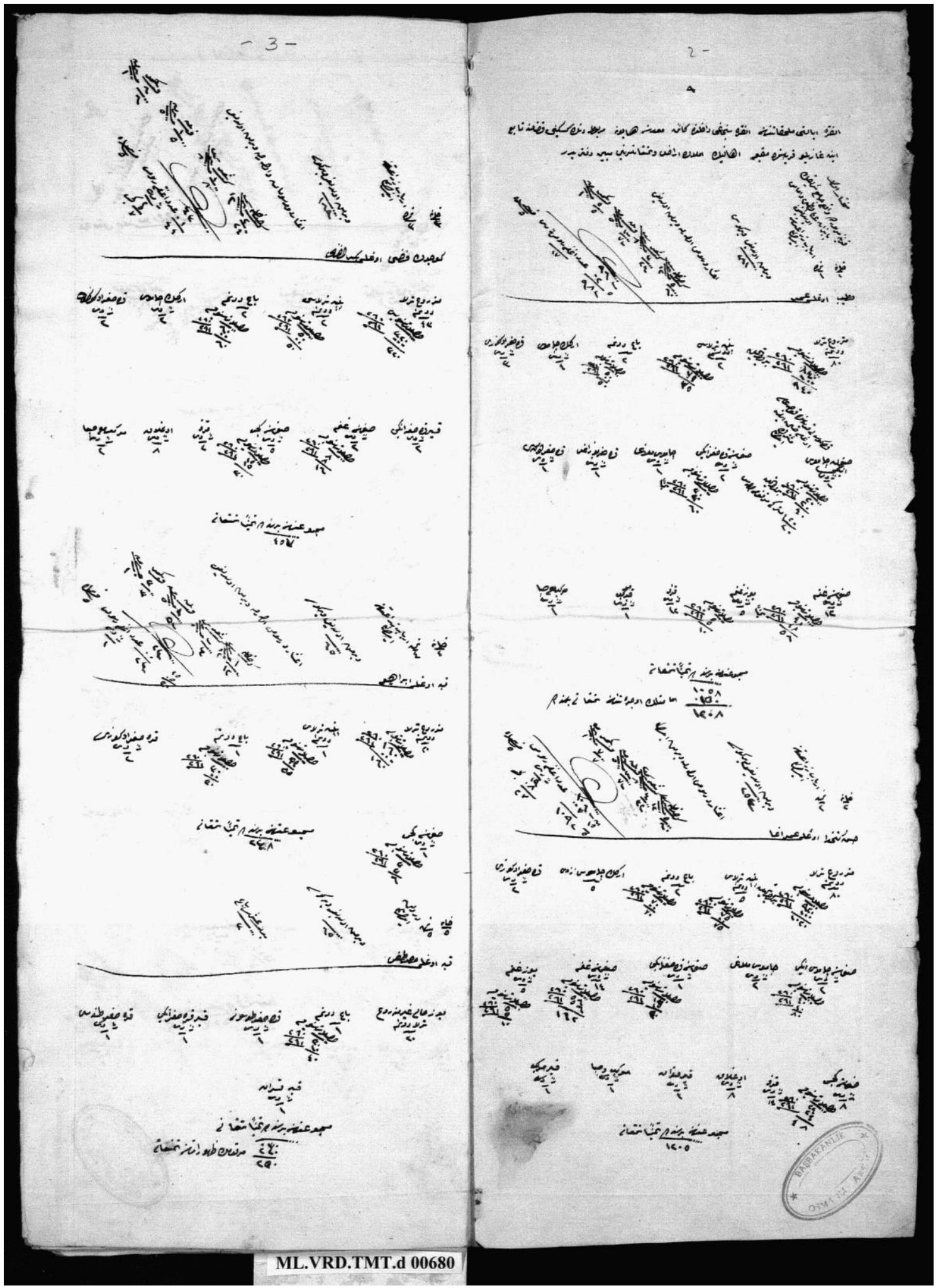




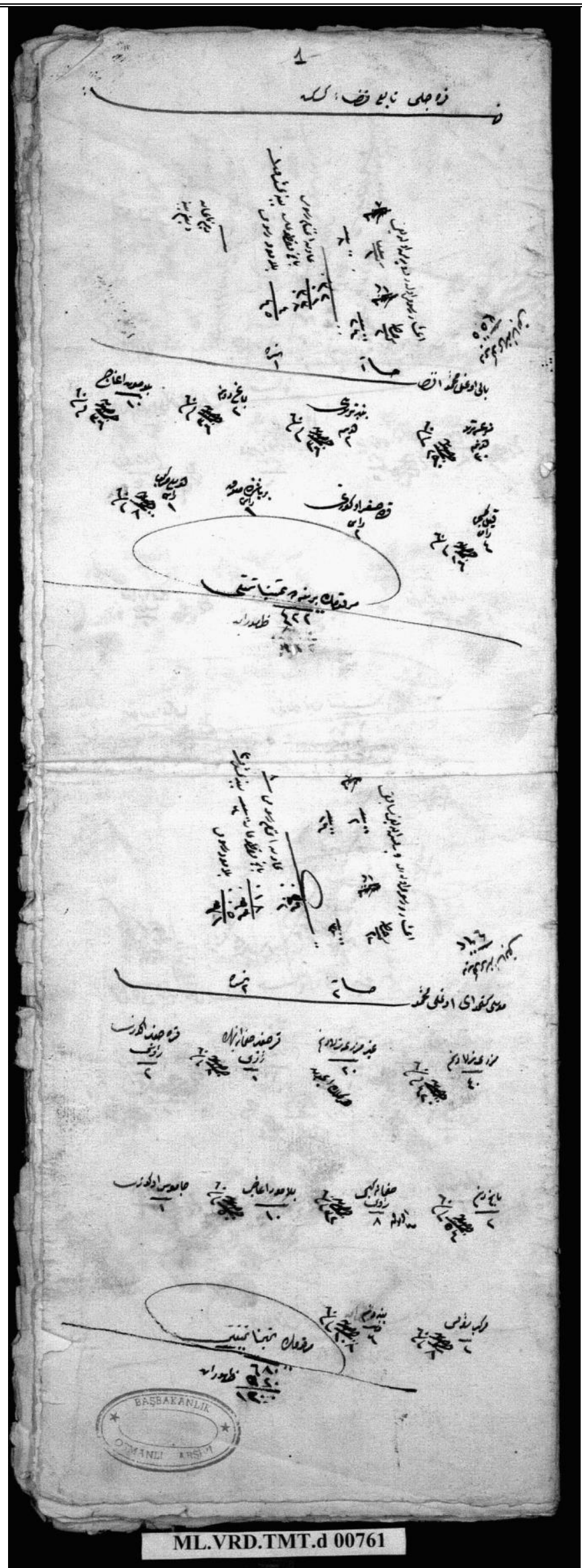

